Wanda Dugiel

\title{
TRANSATLANTYCKIE PARTNERSTWO \\ W DZIEDZINIE HANDLU I INWESTYCJI - WSPARCIE \\ CZY ZAGROŻENIE DLA WIELOSTRONNYCH POROZUMIEŃ MIĘDZYNARODOWYCH?
}

\section{Wprowadzenie}

Prezydent Stanów Zjednoczonych Barack Obama, przewodniczący Komisji Europejskiej José Manuel Barroso oraz przewodniczący Rady Europejskiej Herman Van Rompuy w połowie 2013 r. ogłosili projekt utworzenia Transatlantyckiego Partnerstwa w dziedzinie handlu i inwestycji. Z oświadczenia przywódców wynika, że będzie to kompleksowa umowa gospodarcza w dziedzinie wymiany handlowej i przepływu kapitału, w której ramach powinna powstać również strefa wolnego handlu.

Słabe rezultaty wielostronnych negocjacji handlowych w ramach Rundy rozwojowej z Doha i globalny kryzys gospodarczy przyczyniły się do częstszego podejmowania inicjatyw państw do tworzenia regionalnych ugrupowań integracyjnych w poszukiwaniu nowych rynków zbytu. I tak Stany Zjednoczone negocjują powstanie Transpacyficznego Partnerstwa (Trans-Pacific Partnership) z 11 państwami, w tym z Australią i Japonią. Natomiast Unia Europejska rozpoczęła negocjacje z Indiami i Mercosur. Propozycja Stanów Zjednoczonych utworzenia Transatlantyckiego Partnerstwa w dziedzinie handlu i inwestycji powstała jako próba przeciwstawienia rosnącej pozycji gospodarek wschodzących, w szczególności Chin, w handlu międzynarodowym ${ }^{1}$.

Szereg tematów negocjacyjnych w Transatlantyckim Partnerstwie w dziedzinie handlu i inwestycji wykracza poza regulacje WTO (World Trade Organization), dotyczy to głównie zagadnień barier pozataryfowych, usług oraz przepływu kapitału (inwestycji). Niektóre zagadnienia regulowane przez porozumienia WTO nie będą ujęte w TTIP (Transatlantic Trade and Investment Partnership) ze względu na niechęć Stanów Zjednoczonych i Unii Europejskiej do zwiększenia procesu otwierania

1 Z. Brzezinski, E.U.-U.S. trade pact can halt West's decline, „EU Observer”, Brussels, 19 April 2013. 
wybranych rynków towarów. Dotyczy to wsparcia wewnętrznego w rolnictwie, od dekad skutecznie zniekształcającego międzynarodową wymianę handlową.

Celem opracowania jest zbadanie problemu, czy Transatlantyckie Partnerstwo w dziedzinie handlu i inwestycji, umowa zawarta między najważniejszymi podmiotami handlu międzynarodowego, Stanami Zjednoczonymi i Unią Europejską, będzie źródłem wsparcia liberalizacji na forum WTO, czy wręcz przeciwnie - zagrozi działaniu tej organizacji, która mogłaby przekształcić się w organizację drugorzędną, a duże regionalne bloki handlowe (m.in. TTIP, ASEAN+6) stanowiłyby w przyszłości forum dla liberalizacji handlu międzynarodowego, a nie wielostronne negocjacje w WTO.

Liberalizacja w strefie wolnego handlu nie może kolidować z liberalizacją handlu międzynarodowego. Koszty utworzenia strefy wolnego handlu (efekt przesunięcia handlu) nie mogą przewyższać korzyści (efekt kreacji handlu).

Strefa wolnego handlu w ramach Transatlantyckiego Partnerstwa w dziedzinie handlu i inwestycji według założeń art. XXIV WTO nie powinna dyskryminować krajów trzecich na skutek wystąpienia efektu przesunięcia handlu, lecz prowadzić do osiągnięcia korzyści wewnątrz ugrupowania dzięki wystąpieniu efektu kreacji handlu. Przewaga efektu przesunięcia handlu nad efektem kreacji handlu, czyli zmiana kierunku handlu, zachęci kraje trzecie do tworzenia kolejnych regionalnych ugrupowań integracyjnych oraz ograniczy szanse na przyspieszenie liberalizacji handlu międzynarodowego w Rundzie z Doha. Utworzenie TTIP może w przyszłości zwiększyć protekcjonizm zewnętrzny USA i UE wobec konkurencyjnych gospodarek wschodzących.

W pierwszej części opracowania przeanalizowano najważniejsze przesłanki utworzenia TTIP oraz korzyści i koszty w świetle art. XXIV. W części drugiej porównano dziedziny regulowane w WTO oraz w TTIP oraz przedstawiono najważniejsze kontrowersje związane z włączeniem do umowy TTIP regulacji o ochronie inwestycji w kontekście wykorzystania doświadczeń liberalizacji w TTIP w Rundzie z Doha.

\section{Przesłanki utworzenia Transatlantyckiego Partnerstwa w dziedzinie handlu i inwestycji}

Stany Zjednoczone i Unia Europejska podjęły decyzję o liberalizacji przepływów towarów, usług i kapitału w stosunkach transatlantyckich w okresie wychodzenia ze światowego kryzysu gospodarczego. Liberalizacja barier handlowych w TTIP jest szansą na przyspieszony wzrost gospodarczy i utworzenie nowych miejsce pracy 
dzięki intensyfikacji obrotów handlowych i bezpośrednich inwestycji zagranicznych w okresie spowolnienia gospodarczego na świecie ${ }^{2}$.

Ponadto Transatlantyckie Partnerstwo w dziedzinie handlu i inwestycji zwiększy przeciwwagę dla rosnącej pozycji Chin w gospodarce światowej. Stany Zjednoczone i Unia Europejska wytwarzają prawie 50\% światowego PKB, posiadają znaczny udział w handlu międzynarodowym (30\% światowego eksportu), inwestycje o wartości 3,7 bln USD ${ }^{3}$. Nasilające się zjawisko konkurującego regionalizmu i powstanie nowych ugrupowań integracyjnych, w szczególności ASEAN+6, na skutek wystąpienia efektu przesunięcia handlu wobec krajów trzecich, w tym Stanów Zjednoczonych, może ograniczyć eksport amerykański na rynki państw azjatyckich. TTIP zwiększy PKB USA oraz UE dzięki liberalizacji handlu, rekompensującej straty z pozostawania obu podmiotów poza ugrupowaniami azjatyckimi, które będą zainteresowane kreacją handlu wewnątrz ugrupowań integracyjnych typu ASEAN $+6^{4}$.

Podjęte przez Stany Zjednoczone w trakcie negocjacji Rundy działania na rzecz utworzenia TTIP oraz Transpacyficznego Partnerstwa stanowią zagrożenie dla wielostronnych negocjacji handlowych Rundy rozwojowej z Doha. Stany Zjednoczone powinny znaleźć kompromis w zakresie nowych inicjatyw liberalizacyjnych przepływu towarów i usług z krajami BRICS (Brazylią, Rosją, Indiami, Chinami, RPA) oraz rozwijającymi się na forum WTO, a nie zachęcać własną postawą do tworzenia kolejnych ugrupowań integracyjnych.

Zaangażowanie Stanów Zjednoczonych w integrację regionalną nie musi oznaczać porażki Rundy z Doha. Kompromis w liberalizacji niektórych zagadnień negocjowanych w TTIP Stany Zjednoczone i Unia Europejska mogą wykorzystać do zakończenia Rundy z Doha. Wzajemne porozumienie z Blair House z 1992 r. między USA i UE w dziedzinie liberalizacji handlu rolnego pozwoliło na zakończenie Rundy urugwajskiej w $1994 \mathrm{r}$.

Integracja regionalna może zwiększyć impuls do liberalizacji handlu międzynarodowego dzięki stworzeniu wspólnego stanowiska Stanów Zjednoczonych i Unii Europejskiej w kontrowersyjnych kwestiach negocjacyjnych Rundy z Doha. Negocjacje Rundy urugwajskiej zakończyły się po utworzeniu z inicjatywy Stanów Zjednoczonych Północnoamerykańskiej Strefy Wolnego Handlu (North American Free Trade Agreement, NAFTA). Ponadto o sukcesach kolejnych rund wielostronnych

\footnotetext{
2 European Commission, Final Report High Level Working Group on Jobs and Growth, Brussels, February 11, 2013, http://trade.ec.europa.eu/doclib/docs/2013/february/tradoc_150519.pdf

3 S.I. Akhtar, V.C. Jones, Proposed Transatlantic Trade and Investment Partnership (T-TIP): In Brief, Congressional Research Service, Washington, D.C., June 11, 2014.

4 Remarks by President Obama, U.K. Prime Minister Cameron, European Commission President Barroso, and European Council President Van Rompuy on the Transatlantic Trade and Investment Partnership, For Immediate Release, Northern Ireland, June 17, 2013.
} 
negocjacji handlowych w ramach GATT/WTO decydowała zawsze ścisła współpraca transatlantycka.

Transatlantyckie Partnerstwo w dziedzinie handlu i inwestycji wywołuje kontrowersje społeczne z powodu początkowego utajnienia procesu negocjacji oraz sporów inwestycyjnych, w których inwestor zagraniczny może pozwać państwo. Kontrowersje te doprowadziły do zawieszenia rozmów w pierwszej połowie $2014 \mathrm{r}$. W UE przeciwnicy powstania TTIP, zarówno w Parlamencie Europejskim, jak i w organizacjach pozarządowych, zwracają uwagę na kwestie żywności modyfikowanej genetycznie w USA oraz importu mięsa wołowego $\mathrm{z}$ hormonami wzrostu ${ }^{5}$. W Stanach Zjednoczonych narosły obawy przed dalszą liberalizacją handlu i procesami globalizacji z powodu utraty miejsc pracy, obniżenia płac oraz wzrostu konkurencji z całego świata.

Szanse zawarcia kompleksowej umowy o współpracy gospodarczej wzrosły po upublicznieniu mandatu negocjacyjnego umowy TTIP przez Radę Unii Europejskiej w październiku 2014 r. oraz zwycięstwie Partii Republikańskiej w wyborach do Senatu Stanów Zjednoczonych, mniej sceptycznej odnośnie do skutków globalizacji i umów o wolnym handlu niż Partia Demokratyczna ${ }^{6}$.

\section{Raport Grupy Roboczej Wysokiego Szczebla USA-UE ds. Zatrudnienia i Wzrostu w sprawie kompleksowej umowy handlowo-inwestycyjnej}

Na spotkaniu przywódców Stanów Zjednoczonych i Unii Europejskiej, w dniu 28 listopada 2011 r., powołano Grupę Roboczą Wysokiego Szczebla USA-UE ds. Zatrudnienia i Wzrostu (High Level Working Group on Jobs and Growth, HLWG), która otrzymała zadanie opracowania polityki intensyfikacji stosunków transatlantyckich, zwiększenia wymiany handlowej i inwestycyjnej między Stanami Zjednoczonymi i Unią Europejską, korzystnych dla wzrostu gospodarczego i międzynarodowej konkurencyjności.

Prowadząc prace nad opracowaniem wspólnego stanowiska intensyfikacji obrotów handlowych i inwestycyjnych między Stanami Zjednoczonymi i Unią Europejską, HLWG wydała w 2012 r. raport dla przywódców obu stron o możliwościach liberalizacji

5 R. Benning, S. Börnecke, P. Eberhardt, K. Hansen-Kuhn, H. Lorenzen, A. Spahn, TTIP: No, we Can 't, Kein Freihandelsabkommen Auf Kosten Europäischer Verbraucher! Die Grünen. Europäische Freie Allianz im Europäischen Parlament, Wiesbaden, Dezember 2013.

6 N. Irwin, Where Might Obama and the G.O.P. Agree? Here Are Possibilities, „The New York Times“ November 5, 2014. 
wymiany $^{7}$. W swoim sprawozdaniu końcowym, przyjętym w dniu 11 lutego 2013 r., Grupa Robocza Wysokiego Szczebla zarekomendowała następujące zagadnienia do negocjacji w zakresie dostępu do rynku i barier pozataryfowych:

- wyeliminowanie wszystkich ceł w dwustronnej wymianie handlowej, przy wspólnym dążeniu do znacznego ograniczenia taryf $\mathrm{z}$ chwilą wejścia w życie umowy oraz stopniowego zniesienia wszystkich taryf na produkty wrażliwe w krótkiej perspektywie czasowej;

- powiązanie obecnych autonomicznych poziomów liberalizacji obowiązujących w UE i USA z najwyższym poziomem liberalizacji w obowiązujących umowach o wolnym handlu oraz uzyskanie dostępu do nowych rynków przez pokonanie pozostałych, długotrwałych przeszkód, z uwzględnieniem wrażliwego charakteru niektórych sektorów;

- wynegocjowanie postanowień w zakresie liberalizacji i ochrony inwestycji, aktualnej dla obu stron;

- zwiększenie wzajemnego dostępu do rynku zamówień publicznych na wszystkich poziomach administracyjnych na podstawie zasady traktowania narodowego;

- opracowanie regulacji WTO+, usprawnienie dialogu i współpracy w rozwiązywaniu dwustronnych kwestii w zakresie środków sanitarnych i fitosanitarnych (SPS); postanowienia dotyczące SPS będą oparte na najważniejszych zasadach umowy WTO w sprawie SPS, włącznie z wymogiem, aby środki SPS stosowane przez każdą ze stron miały naukowe podstawy i opierały się na międzynarodowych normach lub naukowych ocenach ryzyka, używane były jedynie w zakresie koniecznym do ochrony życia lub zdrowia ludzi, zwierząt lub roślin i opracowywane z zachowaniem przejrzystości i bez zbędnych opóźnień;

- opracowanie regulacji TBT+ w oparciu o zobowiązania stron podjęte $w$ ramach Porozumienia WTO w sprawie barier technicznych w handlu (Porozumienie TBT), poprawę dialogu i współpracy dla rozwiązań dwustronnych w zakresie TBT (uregulowań technicznych, norm i procedur oceny zgodności); głównym dążeniem stron powinno być ustalenie postanowień o zwiększeniu otwartości, przejrzystości i zbieżności co do stanowisk w zakresie regulacji i wymogów prawnych oraz powiązanych procesów opracowywania norm, w tym norm międzynarodowych, ograniczenie zbędnych i uciążliwych wymogów w zakresie testowania i certyfikacji, budowanie zaufania do właściwych organów zajmujących się oceną zgodności oraz zacieśnianie współpracy w zakresie oceny zgodności i kwestii standaryzacji w wymiarze globalnym.

7 HLWG, Interim Report to Leaders from the Co-Chairs E.U.-U.S., High Level Working Group on Jobs and Growth, 19 June 2012, Washington, Brussels 2012. 
Grupa Robocza Wysokiego Szczebla USA-UE ds. Zatrudnienia i Wzrostu, mając na uwadze wyzwania wielostronnych porozumień handlu międzynarodowego w ramach WTO, zarekomendowała do negocjacji w TTIP następujące kwestie: - wsparcia i egzekwowania przez Unię Europejską i Stany Zjednoczone wysokiego poziomu ochrony własności intelektualnej oraz ujęcia możliwie ograniczonej liczby kwestii w zakresie ochrony własności intelektualnej w negocjacjach;

- objęcia umową o TTIP aspektów handlu i zrównoważonego rozwoju związanych z prawem pracy i środowiskiem;

- osiągnięcia porozumienia dwustronnego w oparciu o zasady globalne, wykraczające poza dyscypliny WTO, w zakresie ułatwień handlowych, polityki konkurencji, energii i surowców, małych i średnich przedsiębiorstw.

Zalecone przez Grupę Roboczą Wysokiego Szczebla USA-UE ds. Zatrudnienia i Wzrostu postulaty do negocjacji umowy o TTIP często wykraczają poza postanowienia porozumień umów międzynarodowych WTO (tabela 1).

W handlu artykułami przemysłowymi eliminacja ceł w TTIP jest zgodna $\mathrm{z}$ ideą Rundy z Doha oraz z regulacjami GATT z 1994 r.

$\mathrm{W}$ handlu rolnym istotne jest zmniejszenie nie tylko barier celnych, ale wsparcia wewnętrznego i subsydiów eksportowych. W Rundzie z Doha osiągnięto postęp w liberalizacji handlu rolnego, na Konferencji ministerialnej w Hongkongu w 2005 r. przyjęto wstępne zobowiązanie o eliminacji subsydiów eksportowych. Stany Zjednoczone i Unia Europejska w coraz mniejszym stopniu wykorzystują subsydia eksportowe jako narzędzia polityki w handlu rolnym, pozostawiając niezliberalizowane narzędzia protekcjonizmu w ramach wsparcia wewnętrznego.

W pozostałych dziedzinach, takich jak usługi, ochrona własności intelektualnej, inwestycje, zamówienie publiczne, środki sanitarne i fitosanitarne, propozycje negocjacyjne w TTIP wykraczają poza uregulowania WTO.

Rozwiązania w umowie dwustronnej między Stanami Zjednoczonymi i Unią Europejską tworzą szansę na wzmocnienie wielostronnych porozumień międzynarodowych WTO, ponieważ przepisy w sprawie liberalizacji usług, inwestycji, prawa pracy, ochrony środowiska, polityki konkurencji, ułatwień handlowych posłużą do uzgodnienia stanowiska w zakresie liberalizacji handlu międzynarodowego w Rundzie z Doha. Realizacja przyjętych w TTIP rozwiązań może stanowić punkt wyjścia propozycji w wielostronnych negocjacjach handlowych. Część tych zagadnień, zamówienia publiczne, ułatwienia handlowe, inwestycje oraz polityka konkurencji z inicjatywy USA i UE były główną przyczyną rozpoczęcia Rundy z Doha w 2001 r., tematy te $\mathrm{w}$ wielostronnych negocjacjach handlowych odrzucili pozostali członkowie WTO w 2003 r. 
Tabela 1. Tematyka negocjacji w TTIP a regulacje WTO

\begin{tabular}{|c|c|c|}
\hline $\begin{array}{l}\text { Problematyka } \\
\text { negocjacji }\end{array}$ & Wytyczne mandatu negocjacyjnego & Regulacje WTO \\
\hline Taryfy celne & $\begin{array}{l}\text { eliminacja taryf celnych po wejściu w życie } \\
\text { umowy o TTIP oraz w krótkim okresie ceł } \\
\text { na towary wrażliwe }\end{array}$ & $\begin{array}{l}\text { porozumienie GATT z } 1994 \text { r.: art. II w sprawie } \\
\text { list koncesji krajowych; art. XXIV w sprawie } \\
\text { kryteriów przegladdu stref wolnego handlu } \\
\text { i wpływu na kraje trzecie }\end{array}$ \\
\hline Rolnictwo & $\begin{array}{l}\text { eliminacja taryf celnych i barier pozataryfowych } \\
\text { (kwestie dostępu do rynku) }\end{array}$ & $\begin{array}{l}\text { porozumienie w sprawie rolnictwa } \\
\text { dostęp do rynku (art. 4) } \\
\text { wsparcie wewnętrzne (art. 6) } \\
\text { subsydia eksportowe (art. 7) }\end{array}$ \\
\hline Usługi & $\begin{array}{l}\text { najwyższy poziom liberalizacji } \\
\text { w umowach o wolnym handlu; uzyskanie } \\
\text { dostępu do rynku } \\
\text { lista negatywna }\end{array}$ & $\begin{array}{l}\text { dostęp do rynku (art. XVI GATS) Układ Ogólny } \\
\text { w sprawie Usług } \\
\text { zasada traktowania narodowego (art. XVII } \\
\text { GATS) }\end{array}$ \\
\hline Inwestycje & $\begin{array}{l}\text { liberalizacja i ochrona inwestorów w oparciu } \\
\text { o dotychczasowe umowy o wolnym handlu }\end{array}$ & $\begin{array}{l}\text { nie uregulowano w WTO (uregulowano jedynie } \\
\text { kwestie handlowe związane z inwestycjami) }\end{array}$ \\
\hline $\begin{array}{l}\text { Zamówienia } \\
\text { publiczne }\end{array}$ & $\begin{array}{l}\text { dostęp do rynku zamówień publicznych } \\
\text { na wszystkich poziomach administracyjnych }\end{array}$ & $\begin{array}{l}\text { kilkustronne Porozumienie w sprawie } \\
\text { zamówień rządowych }\end{array}$ \\
\hline $\begin{array}{l}\text { Środki sanitarne } \\
\text { i fitosanitarne }\end{array}$ & $\begin{array}{l}\text { ustanowienie środków SPS na podstawie } \\
\text { naukowych podstaw }\end{array}$ & $\begin{array}{l}\text { Porozumienie w sprawie stosowania środków } \\
\text { sanitarnych i fitosanitarnych }\end{array}$ \\
\hline Bariery techniczne & $\begin{array}{l}\text { zwiększenie przejrzystości regulacji } \\
\text { w uznawaniu norm }\end{array}$ & $\begin{array}{l}\text { Porozumienie WTO w sprawie barier } \\
\text { technicznych w handlu (porozumienie TBT) }\end{array}$ \\
\hline $\begin{array}{l}\text { Ochrona własności } \\
\text { intelektualnej }\end{array}$ & ochrona i uznawanie oznaczeń geograficznych & $\begin{array}{l}\text { znaki towarowe (art. } 15 \text { ust. } 1 \text { TRIPS) } \\
\text { oznaczenia geograficzne (art. } 22 \text { ust. } 1 \text { TRIPS) } \\
\text { patenty (art. } 27 \text { ust. } 1 \text { TRIPS) }\end{array}$ \\
\hline $\begin{array}{l}\text { Ochrona środowiska } \\
\text { i standardy pracy }\end{array}$ & $\begin{array}{l}\text { uznanie norm i umów w obszarze prawa pracy } \\
\text { i ochrony środowiska }\end{array}$ & nie uregulowano w WTO \\
\hline $\begin{array}{l}\text { Kwestie } \\
\text { pozahandlowe }\end{array}$ & polityka konkurencji & nie uregulowano w WTO \\
\hline
\end{tabular}

${ }^{a}$ Lista negatywna oznacza zastosowanie liberalizacji wobec wszystkich usług, z określonymi wyjątkami podsektorów usług objętych liberalizacją. Natomiast lista pozytywna oznacza liczbę podsektorów usług, wobec których obowiązują regulacje GATS.

Źródło: Rada Unii Europejskiej, Wytyczne dotyczące negocjacji w sprawie kompleksowej umowy handlowo-inwestycyjnej, zwanej transatlantyckim partnerstwem w sprawie handlu i inwestycji, między Unią Europejską a Stanami Zjednoczonymi Ameryki, 11103/13 DCL 1, Bruksela, 9 października 2014 r.; Obwieszczenie Ministra Spraw Zagranicznych z dnia 4 grudnia 1995 r. w sprawie publikacji załączników do Porozumienia ustanawiającego Światową Organizację Handlu (WTO), DzU.1996.9.54.

\section{Korzyści z utworzenia strefy wolnego handlu według art. XXIV GATT z 1994 r.}

Podejmując decyzję o utworzeniu TTIP, przywódcy państw wybrali rozwiązanie liberalne w polityce gospodarczej, wynikające z teorii wymiany gospodarczej, z których wywodzi się teoria integracji gospodarczej. 
Z teorii integracji gospodarczej wynika, iż powstanie strefy wolnego handlu ${ }^{8}$ prowadzi do powstania efektów krótkookresowych: kreacji handlu (trade creation effect), pozytywnego dla dobrobytu państw członkowskich, oraz przesunięcia (zmiany kierunków) handlu (trade diversion effect), negatywnego zarówno dla krajów członkowskich, jak i trzecich. Efekt kreacji polega na wzroście obrotów handlowych między członkami strefy wolnego handlu. Efekt przesunięcia polega na ograniczeniu obrotów handlowych krajów strefy wolnego handlu z państwami trzecimi (tańszymi producentami) na skutek wzrostu obrotów handlowych między krajami strefy 9 .

Przewaga efektu przesunięcia nad efektem kreacji zwiększy straty krajów trzecich pozostających poza strefą wolnego handlu, obniży ich dobrobyt. Wystąpienie niekorzystnego efektu przesunięcia handlu zaprzecza idei wolnego handlu, na której oparto zasady GATT/WTO. Państwa spoza TTIP będą odbierać dyskryminację ich eksportu na rynek amerykański i europejski jako działania protekcjonistyczne i brak zainteresowania procesem liberalizacji na forum WTO.

Siła wystąpienia efektu kreacji handlu uzależniona jest od następujących kryteriów: (1) wielkości strefy wolnego handlu, tj. liczby państw członkowskich oraz ich udziału w handlu światowym ${ }^{10}$; (2) roli handlu wewnątrzregionalnego (intra-regional) w całości wymiany handlowej członków strefy wolnego handlu ${ }^{11}$; (3) integracji wszystkich sektorów w strefie wolnego handlu; (4) wyjściowego poziomu barier handlowych w obrocie wzajemnym przed utworzeniem strefy ${ }^{12}$.

Transatlantyckie Partnerstwo w dziedzinie handlu i inwestycji spełnia kryteria warunkujące zwiększenie siły wystąpienia efektu kreacji handlu i uzyskania przewagi nad efektem przesunięcia.

8 Istota pełnej strefy wolnego handlu sprowadza się do całkowitego zniesienia ceł, ograniczeń ilościowych i innych barier swobodnego handlu towarami między krajami członkowskimi strefy, z tym jednak, że każdy z nich dysponuje prawem do autonomicznej polityki ekonomicznej (w tym handlowej) w obrotach $\mathrm{z}$ krajami trzecimi.

9 Integracja europejska. Wybrane problemy, red. D. Milczarek, A.Z. Nowak, Centrum Europejskie Uniwersytetu Warszawskiego, Warszawa 2003.

10 Przy większej liczbie członków producenci obniżają koszty i osiągają specjalizację, zgodnie z teorią handlu międzynarodowego. Jeżeli ten warunek jest spełniony, wystąpi większy efekt kreacji handlu, przy pomniejszonych tendencjach do wystąpienia efektu przesunięcia handlu. Por. P. Robson, The Economics of International Integration, $3^{\text {rd }}$ ed., Allen and Unwin, Boston, Sydney 1987.

${ }^{11}$ Im większy jest udział handlu wewnątrzregionalnego (intra-regional) w całości wymiany handlowej krajów członkowskich strefy wolnego handlu lub unii celnej, tym większe prawdopodobieństwo, iż efekt kreacji handlu będzie większy niż efekt przesunięcia handlu. Oznacza to, że większe istniejące powiązania handlowe doprowadzą do przesunięcia $z$ niskich kosztów firm poza regionem do firm o wyższych kosztach w regionie. J. Bhagwati, Regionalism v. Multilateralism, „World Economy” 15-5, Wiley Online Library, September 1992.

12 Udział wszystkich sektorów zwiększy prawdopodobieństwo, że kraje członkowskie po integracji wykorzystają przewagi komparatywne (comparative advantage) na niektóre produkty. 
Po pierwsze, Unia Europejska i Stany Zjednoczone należą do najważniejszych podmiotów w handlu międzynarodowym. Ich udział w światowym eksporcie w $2013 \mathrm{r}$. wyniósł 25,8\% (tabela 2). W porównaniu z latami 90. XX w. udział ten jest coraz mniejszy, na korzyść Chin oraz Brazylii i Indii, co stwarza przesłanki do integracji transatlantyckiej. Strefa wolnego handlu w ramach Transatlantyckiego Partnerstwa w zakresie handlu i inwestycji będzie jednym z największych obszarów integracyjnych na świecie z liczbą 29 członków.

Tabela 2. Udział Unii Europejskiej i Stanów Zjednoczonych w światowym eksporcie w latach 1990-2013 (w \%)

\begin{tabular}{|l|r|r|r|r|r|r|}
\hline \multicolumn{1}{|c|}{ Podmiot } & 1990 & 1995 & 2000 & 2005 & 2010 & 2013 \\
\hline UE $^{\mathrm{a}}$ & 21,8 & 20,0 & 17,3 & 17,1 & 15,0 & 15,3 \\
\hline Stany Zjednoczone & 15,7 & 15,5 & 15,7 & 11,7 & 10,8 & 10,5 \\
\hline Brazylia & 1,1 & 1,2 & 1,1 & 1,5 & 1,7 & 1,6 \\
\hline Chiny & 2,6 & 4,0 & 5,0 & 9,8 & 13,3 & 14,7 \\
\hline Indie & 0,7 & 0,8 & 0,9 & 1,2 & 1,8 & 2,1 \\
\hline
\end{tabular}

${ }^{a} \mathrm{Z}$ wyłączeniem handlu wewnątrz Unii Europejskiej.

Źródło: World Trade Report 2011, s. 34; WTO, International Trade Statistics 2006, s. 18; http://www.wto. org/english/news_e/pres96_e/pr044_e.htm\#Footnote4; External and intra-EU trade. A Statistical Yearbook 1958-2010, European Union, Eurostat, Statistical Books, Luxembourg 2011.

Po drugie, nadal istotną rolę w całości wymiany Stanów Zjednoczonych i Unii Europejskiej odgrywa handel wewnątrzregionalny (tabela 3). Unia Europejska należy do najważniejszych partnerów handlowych Stanów Zjednoczonych. W 2013 r. udział UE w eksporcie zewnętrznym wyniósł 16,7\%, w porównaniu z 26,3\% w 1990 r. Zmniejszenie roli Unii Europejskiej w eksporcie Stanów Zjednoczonych jest wynikiem wzrostu znaczenia krajów NAFTA (Kanady i Meksyku) oraz państw BRICS (Brazylii, Rosji, Indii, Chin i RPA) w handlu USA. Podobne tendencje występują po stronie importu Stanów Zjednoczonych z Unii Europejskiej.

Po trzecie, procesem integracji transatlantyckiej objęto wszystkie sektory, w tym najbardziej „wrażliwy” sektor rolny. Propozycja liberalizacji handlu rolnego w TTIP dotyczy wyłącznie barier celnych i niektórych pozataryfowych (środków ochrony zdrowia i życia konsumentów). Ze względu na utrzymanie wysokiego poziomu protekcjonizmu w rolnictwie USA i UE zrezygnowały z liberalizacji wsparcia wewnętrznego.

Unia Europejska należy do ważniejszych partnerów handlowych Stanów Zjednoczonych w zakresie artykułów rolnych. Eksport Stanów Zjednoczonych do Unii Europejskiej wzrósł z ponad 5 mld USD w 2005 r. do poziomu 7,3 mld USD w $2013 \mathrm{r}$. 
(rysunek 1) ${ }^{13}$. Udział Unii Europejskiej w eksporcie rolnym Stanów Zjednoczonych wyniósł niecałe 10\%, w imporcie rolnym nie przekroczył 3\%. Po stronie eksportu Stanów Zjednoczonych w handlu rolnym najważniejsze miejsce zajmowały Chiny (27\% całości eksportu rolnego) oraz Kanada. Największy pod względem wartości import do Stanów Zjednoczonych pochodził z krajów pozaeuropejskich ${ }^{14}$. Począwszy od 2005 r., Stany Zjednoczone osiągają dodatnie saldo bilansu handlowego artykułami rolnymi, nadwyżka wzrosła z poziomu 3,7 mld USD w 2005 r. do 5,7 mld USD w $2013 \mathrm{r}$.

Tabela 3. Handel wewnątrzregionalny w Transatlantyckim Partnerstwie w dziedzinie handlu i inwestycji

\begin{tabular}{|l|c|c|c|c|c|c|}
\hline & 1990 & 1995 & 2000 & 2005 & 2010 & 2013 \\
\hline \multicolumn{7}{|c|}{ Udziat Stanów Zjednoczonych w handlu zewnętrznym UE } \\
\hline Eksport & 19,2 & 18,0 & 28,0 & 23,9 & 18,0 & 16,6 \\
\hline Import & 16,9 & 19,0 & 20,8 & 13,4 & 12,7 & 11,7 \\
\hline \multicolumn{7}{|c|}{ Udział UE w handlu zewnętrznym Stanów Zjednoczonych } \\
\hline Eksport & 26,3 & 24,5 & 21,5 & 20,8 & 18,7 & 16,7 \\
\hline Import & 20,0 & 19,2 & 18,6 & 18,5 & 16,6 & 17,1 \\
\hline
\end{tabular}

Źródło: European Union, Trade in goods with USA, European Commission, Directorate-General for Trade, Brussels, 27.08.2014, http://trade.ec.europa.eu/doclib/docs/2006/september/tradoc_113465.pdf; External and intra-EU trade..., op.cit.

Po czwarte, jednym z kryteriów zwiększenia siły wystąpienia efektu kreacji handlu jest wyjściowy poziom taryf celnych i barier pozataryfowych między stronami TTIP: im wyższy jest poziom barier przed utworzeniem strefy wolnego handlu, tym wyższe rozmiary osiągnie efekt kreacji handlu.

Cła w stosunkach transatlantyckich liberalizacji taryf celnych w kolejnych rundach GATT/WTO osiągnęły niski poziom. Średnia taryfa celna w Unii Europejskiej jest wyższa niż w Stanach Zjednoczonych, w 2010 r. wynosiła 3,3\%, podczas gdy w USA średni poziom taryfy celnej wynosił $2,2 \%$ (rysunek 3). Eliminacja barier celnych otworzy europejski rynek zbytu, a artykuły przemysłowe ze Stanów Zjednoczonych uzyskają podobne warunki dostępu do rynku UE jak wielu innych partnerów handlowych: Chile, Meksyk, Korea Płd.

${ }^{13}$ Na podstawie danych statystycznych udostępnionych przez United States Department of Commerce, Bureau of the Census, Foreign Trade Division TPIS Database: USHS.

${ }_{14}$ Z Kanady (18\%), Meksyku (17,9\%), Chile (6,2\%), Indonezji (5,9\%), Chin (5,6\%), Wietnamu (4,2\%), Brazylii (4\%), Indii (3,5\%), Kolumbii (5,4\%), Ekwadoru (3\%). 


\section{Rysunek 1. Eksport artykułów rolnych Stanów Zjednoczonych do Unii Europejskiej w latach 2005-2013 (w mln USD)}

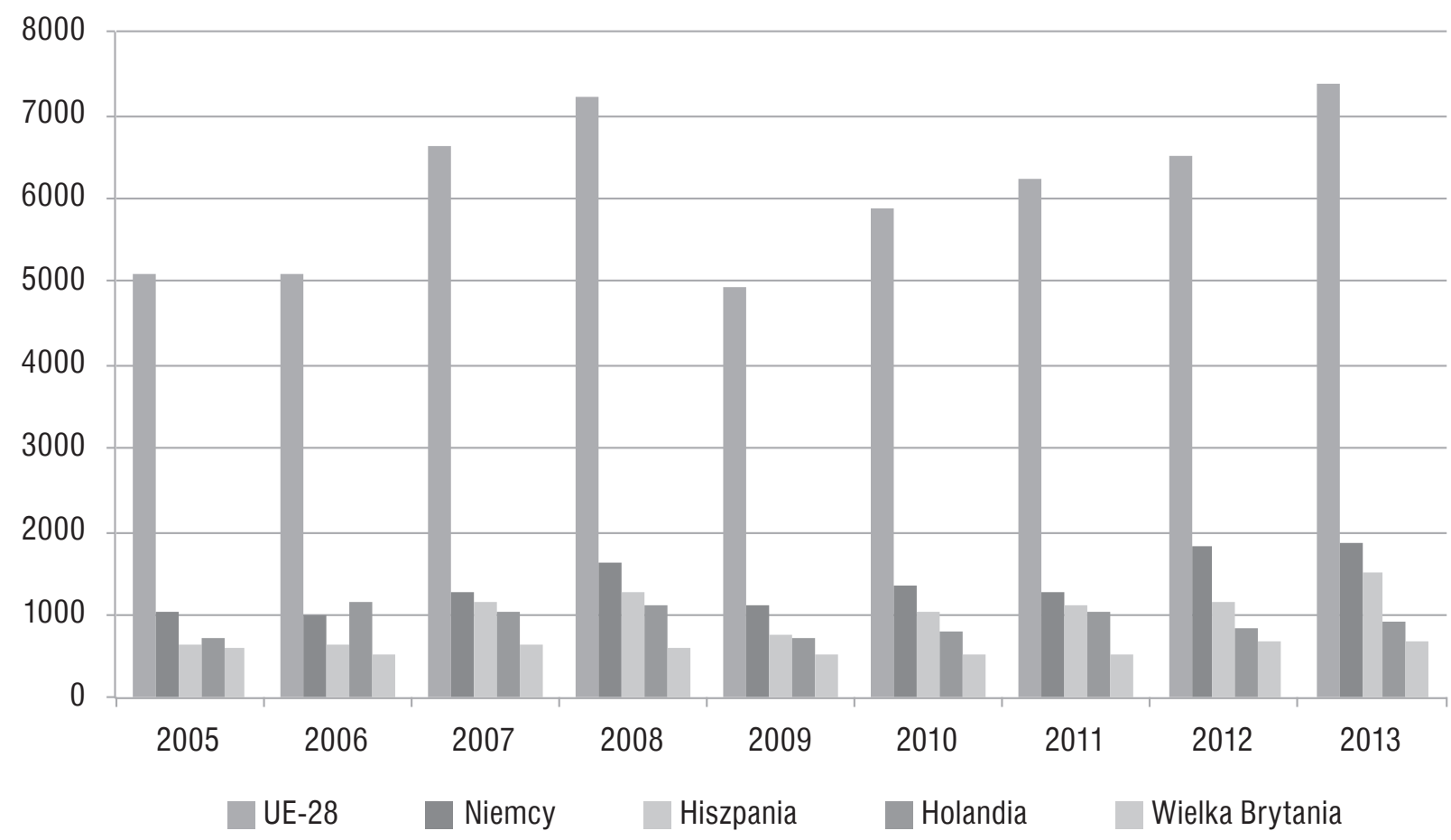

Źródło: United States Department of Commerce, Bureau of the Census, Foreign Trade Division TPIS Database: USHS, http://tpis7.ita.doc.gov/TPIS_GREPORTS/tpis_ustopctys1.aspx

\section{Rysunek 2. Import artykułów rolnych do Stanów Zjednoczonych z Unii Europejskiej} w latach 2005-2013 (w mld USD)

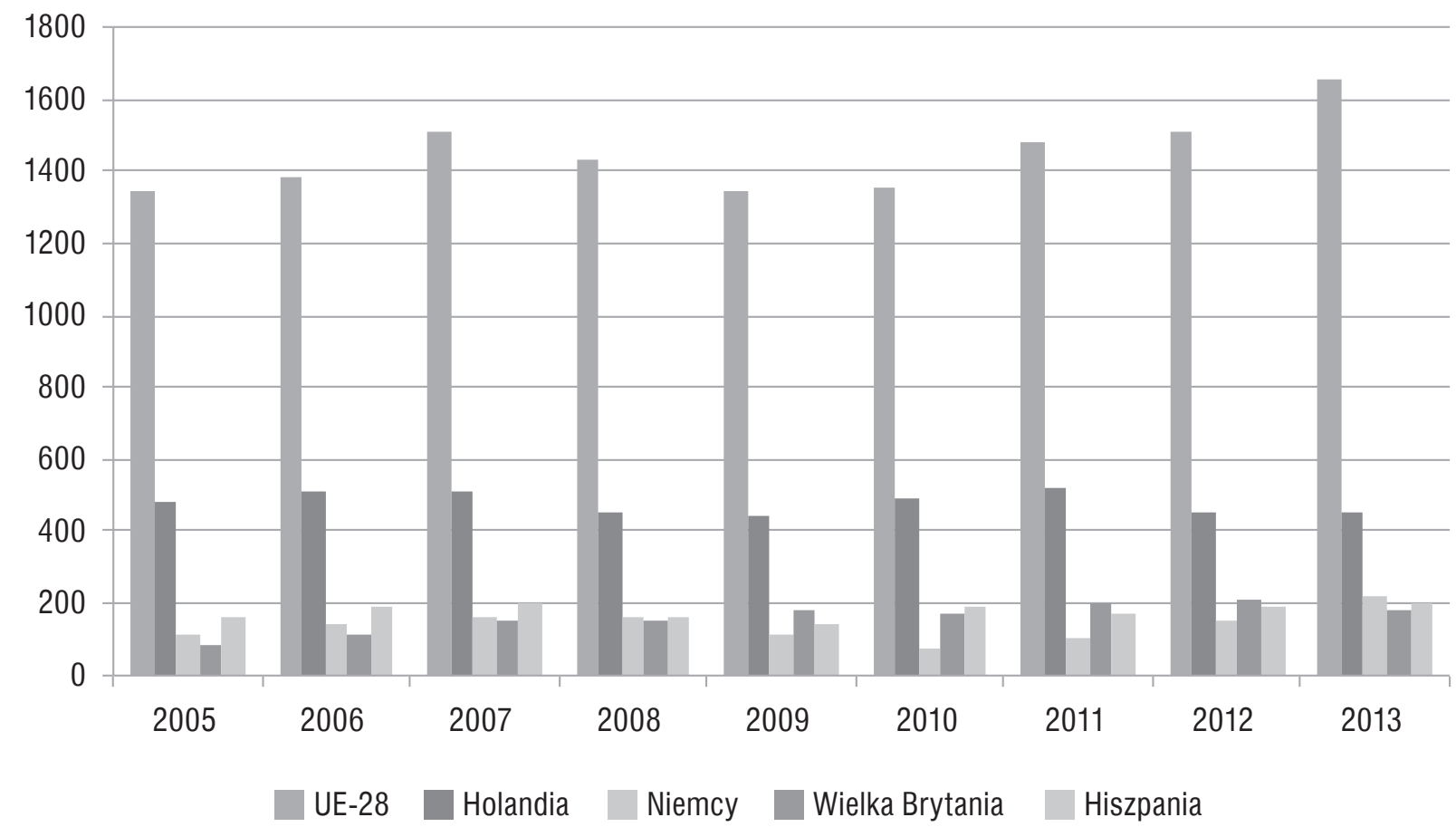

Źródło: United States Department of Commerce, op.cit. 


\section{Rysunek 3. Średnia stosowana taryfa celna przez Stany Zjednoczone i Unię Europejską w relacjach dwustronnych $w 2010$ r. ( $w \%$ )}

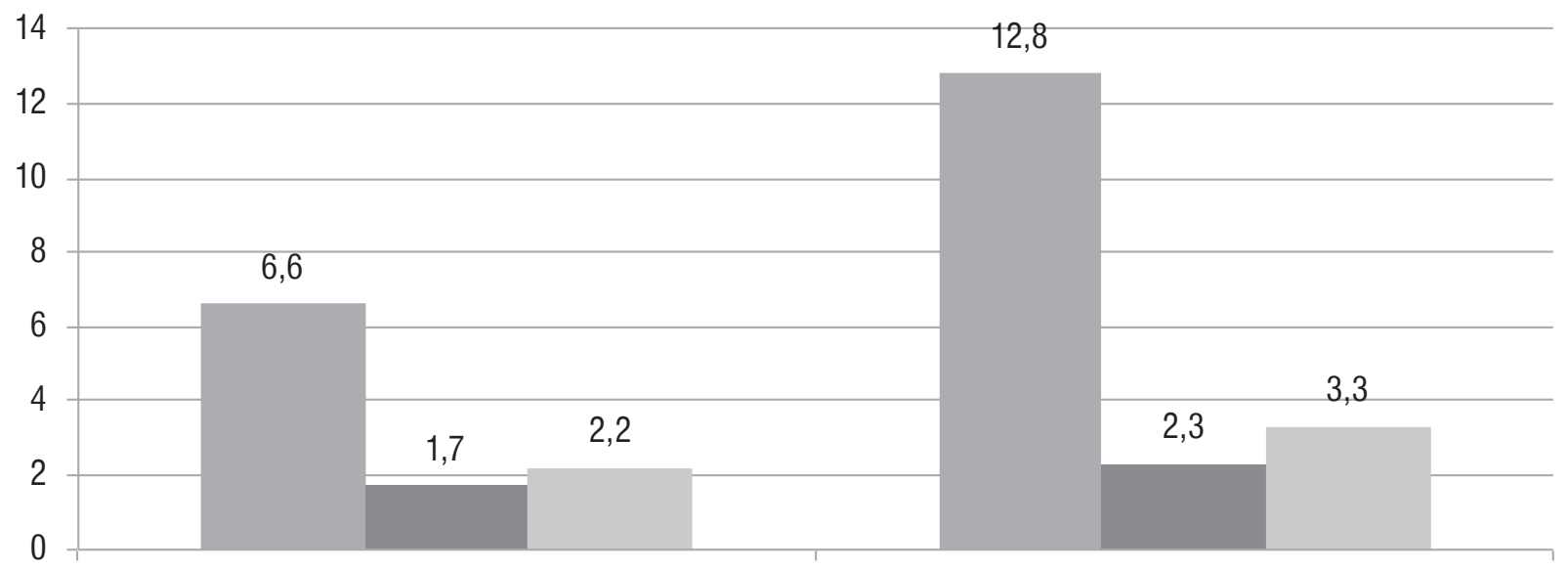

w Stanach Zjednoczonych na import z UE

w UE na import ze Stanów Zjednoczonych
artykuły rolne
artykuły przemystowe
wszystkie

Źródło: L. Fontagné, J. Gourdon, S. Jean, Transatlantic Trade: Whither Partnership, Which Economic Consequences?, „CEPII - Policy Brief” September 2013, No. 1.

\section{Ramka 1. Taryfy celne w imporcie rolnym w Stanach Zjednoczonych i w Unii Europejskiej}

\begin{tabular}{|c|c|c|c|c|c|c|}
\hline \multicolumn{7}{|c|}{$\begin{array}{l}\text { Na podstawie postanowien Rundy urugwajskiej Stany Zjednoczone zobc } \\
\text { na artykuły rolne na poziomie } 4,9 \% \text { ad valorem. Stany Zjednoczone zobo } \\
\text { rolne jako wolne od ceł i dodatkowe na } 44,3 \% \text { linii taryfowych ustalor } \\
\text { więc ponad } 74 \% \text { linii taryfowych w USA na artykuły rolne może osia } \\
\text { linii taryfowych w Stanach Zjednoczonych na artykuły rolne i } 2,9 \% \text { sp }\end{array}$} \\
\hline \multirow{2}{*}{ Nazwa produktu } & \multicolumn{3}{|c|}{ Stawka celna związana } & \multicolumn{3}{|c|}{ Stawka celna stosowana } \\
\hline & średnia & bezcłowy & maks. & średnia & bezcłowy & maks. \\
\hline Produkty zwierzęce & 2,4 & 30,8 & 26 & 2,3 & 30,8 & 26 \\
\hline Mleko i przetwory mleczne & 19,9 & 0,3 & 93 & 20,5 & 0,3 & 93 \\
\hline Napoje i tytoń & 15,3 & 27,1 & 350 & 18,9 & 26,2 & 350 \\
\hline \multicolumn{7}{|c|}{$\begin{array}{l}\text { Dla Unii Europejskiej średnia związana taryfa celna na import produktów rolnych wynosi } 13,8 \% \text { ad valorem. Na niecałe } 32 \% \text { tary } \\
\text { linii rolnych stosowana jest zerowa taryfa celna, a na } 9,8 \% \text { linii taryfowych stosowana jest co najwyżej taryfa celna } 5 \% \text {. Tak wie } \\
\text { na } 41 \% \text { linii taryfowych na produkty rolne w UE średnia taryfa celna stosowana wynosi } 5 \% \text {. Kontyngentami taryfowymi wpływ } \\
11,3 \% \text { unijnych linii taryfowych na artykuły rolne i } 23,9 \% \text { korzysta ze specjalnych środków ochronnych. }\end{array}$} \\
\hline \multirow{2}{*}{ Nazwa produktu } & \multicolumn{3}{|c|}{ Stawka celna związana } & \multicolumn{3}{|c|}{ Stawka celna stosowana } \\
\hline & średnia & bezcłowy & maks. & średnia & bezcłowy & maks. \\
\hline Produkty zwierzęce & 23,2 & 20,6 & 133 & 20,0 & 27,3 & 133 \\
\hline Mleko i przetwory mleczne & 53,0 & 9,0 & 597 & 52,8 & 0 & 511 \\
\hline Napoje i tytoń & 21,2 & 23,0 & 165 & 20,8 & 18,8 & 162 \\
\hline
\end{tabular}

Źródło: WTO, ITC, UNCTAD, World Tariff Profiles 2014, Geneva 2014, s. 168. 
W obrotach wzajemnych nadal wysokie stawki celne utrzymują się w handlu rolnym, co wynika z protekcjonistycznej polityki USA i UE w tym sektorze (ramka 1). Wysokie cła w strefie wolnego handlu w TTIP wobec państw trzecich będą sprzyjać powiększeniu efektu przesunięcia handlu.

Wysoki poziom protekcjonizmu utrzymuje się w przypadku barier pozataryfowych. Unia Europejska stosuje najwyższe bariery pozataryfowe w handlu rolnym, Stany Zjednoczone - na usługi finansowe ${ }^{15}$.

Stany Zjednoczone dążą do wyeliminowania lub ograniczenia barier pozataryfowych, których działanie w zakresie ograniczenia konkurencyjnego importu jest bardziej skuteczne niż w przypadku ustanowienia ceł. Negatywne skutki stosowania barier technicznych można ograniczyć dzięki ustanowieniu standardów wzajemnego uznawania produktów, wzajemnego uznawania norm. Podobny system uznawania norm technicznych uregulowano do $1992 \mathrm{r}$. w ramach jednolitego rynku europejskiego, eliminując bariery techniczne (np. na samochody, chemikalia).

Podsumowując, korzyści z utworzenia TTIP w ujęciu nominalnym nie przedstawiają dużych wartości. Korzyści z utworzenia Transatlantyckiego Partnerstwa w dziedzinie handlu i inwestycji Ośrodek Badań Polityki Gospodarczej (Centre for Economic Policy Research, CEPR) oszacował na poziomie 0,5\% i 0,4\% PKB, odpowiednio dla Stanów Zjednoczonych i Unii Europejskiej do 2027 r. Z badania CEPR wynika, iż korzyści dla UE wyniosą 119 mld euro rocznie, co odpowiada dodatkowym 545 euro dla gospodarstwa domowego, Stany Zjednoczone zyskają dodatkowe 95 mld euro rocznie - 655 euro przypada na rodzinę amerykańską. Według szacunków CEPII (Centre d'Etudes Prospectives et d'Informations Internationales) wymiana handlowa towarów i usług między UE i USA wzrośnie o blisko 50\% po podpisaniu umowy $^{16}$. Największe korzyści po zniesieniu ceł i barier pozataryfowych dotyczą handlu rolnego, który wzrośnie dzięki liberalizacji średnio o 150\%, skromniejsze wyniki wzrostu wymiany wystąpią w przepływie usług (niecałe 15\% dla USA i 24\% dla UE).

Szansą na zwiększenie korzyści z umowy TTIP będą korzyści długookresowe, ustanowienie wspólnych regulacji prawnych w wymianie oraz korzyści skali dla firm ${ }^{17}$.

Przy tak niskich korzyściach z powstania TTIP Stany Zjednoczone i Unia Europejska ryzykują utratę wiarygodności w sprawowaniu roli orędowników idei wolnego

15 J. Francois, M. Manchin, H. Norberg, O. Pindyuk, P. Tomberger, Reducing Transatlantic Barriers to Trade and Investment An Economic Assessment, Final Project Report, March 2013, Prepared under implementing Framework Contract TRADE10/A2/A16, Centre for Economic Policy Research, London 2013.

16 L. Fontagné, J. Gourdon, S. Jean, Transatlantic Trade: Whither Partnership, Which Economic Consequences?, „CEPII - Policy Brief” September 2013, No. 1.

17 European Commission, Transatlantic Trade and Investment Partnership, The Economic Analysis Explained, Brussels, September 2013, http://www.cepr.org/content/independent-study-outlines-benefits -eu-us-trade-agreement 
handlu na świecie w GATT/WTO i przywództwa w zakresie liberalizacji handlu międzynarodowego. Przywództwo dwóch potęg Stanów Zjednoczonych i Unii Europejskiej w okresie powojennym pozwalało zjednoczyć wokół nich państwa rozwijające się w realizacji procesu liberalizacji handlu międzynarodowego.

\section{Koszty utworzenia strefy wolnego handlu w świetle art. XXIV GATT z 1994 r.}

W świetle teorii integracji gospodarczej, na której oparto zasady WTO, efekt przesunięcia handlu prowadzi do obniżenia dobrobytu krajów trzecich i członkowskich strefy. WTO jest gwarantem udziału wszystkich państw członkowskich w handlu międzynarodowym na równorzędnych prawach, bez dyskryminowania pozostałych członków, zgodnie z klauzulą największego uprzywilejowania. Państwo przyznając koncesje handlowe jednemu partnerowi handlowemu, zobowiązane jest do rozszerzenia tych koncesji wobec pozostałych państw (art. I GATT z 1994 r.). Tak sformułowana zasada odzwierciedla ideę teorii wymiany międzynarodowej o korzyściach z wolnego handlu.

Umawiające się strony GATT w 1947 r., dysponując jedynie teoriami wymiany międzynarodowej, uznały, iż strefy wolnego handlu i unie celne, naruszające zasadę niedyskryminacji, nie powinny prowadzić do pogorszenia dobrobytu krajów trzecich. Szybko rozwijająca się, począwszy od lat 50. XX w., teoria integracji gospodarczej już po utworzeniu GATT w $1947 \mathrm{r}$. potwierdziła powstawanie ujemnych dla dobrobytu skutków w formie efektu przesunięcia handlu. Istotę teorii integracji gospodarczej uwzględniono w postanowieniach art. XXIV GATT z 1994 r., w którym ujęto warunki niezbędne do ograniczenia rozmiarów efektu przesunięcia handlu.

I tak w art. XXIV:5 GATT z 1994 r. przyjęto wobec członków stref wolnego handlu lub unii celnych wymaganie niewznoszenia wyższych lub bardziej restrykcyjnych taryf celnych lub barier pozataryfowych niż istniejące przed integracją.

Ponadto w art. XXIV:8 przyjęto wymóg zniesienia ceł i innych ograniczeń handlowych odnośnie do praktycznie całego handlu , substantially all” pomiędzy terytoriami wchodzącymi w skład ugrupowania integracyjnego. Regulacje te, w myśl teorii integracji gospodarczej, pozwalają na zwiększenie efektu kreacji handlu, pozytywnego dla dobrobytu członków strefy wolnego handlu i unii celnych.

Weryfikacja postanowień art. XXIV w strefach wolnego handlu oraz uniach celnych wskazuje, iż większość ugrupowań integracyjnych nie spełniała regulacji GATT. Najczęstszym problemem okazała się integracja całości handlu, tj. wszystkich sektorów gospodarki. 
Niektóre ugrupowania integracyjne w Europie, powstałe w latach 50. XX w., takie jak Europejska Wspólnota Węgla i Stali (EWWiS) oraz Europejskie Stowarzyszenie Wolnego Handlu (EFTA), nie spełniały wymogów art. XXIV GATT z 1947 r. Pierwsza ze Wspólnot Europejskich, utworzona w 1951 r. przez 6 państw założycielskich jako Europejska Wspólnota Węgla i Stali, obejmowała wyłącznie węgiel brunatny, żelazo, złom stalowy. Wymiana między państwami EWWiS nie stanowiła całej wymiany handlowej (art. XXIV:8). GATT zezwolił na powstanie EWWiS na podstawie zwolnienia niektórych państw z obowiązków wynikających z wielostronnej umowy GATT z 1947 r. (tzw. waiver) w myśl art. XXV:5 GATT z 1947 r. Podobnie integracja EFTA nie objęła całości wymiany handlowej, państwa członkowskie wykluczyły sektor rolny ze strefy wolnego handlu.

Zniesienie ceł i innych ograniczeń w handlu w ramach strefy wolnego handlu powinno być osiągnięte „w rozsądnym czasie”, co oznacza okres nie dłuższy niż 10 lat (art. XXIV GATT). Państwa członkowskie zobowiązane są do notyfikacji do WTO projektu utworzenia strefy wolnego handlu.

Im wyższe taryfy celne wobec nieczłonków po utworzeniu strefy wolnego handlu, tym większe zagrożenie wystąpienia ujemnego dla dobrobytu krajów członkowskich strefy oraz krajów trzecich efektu przesunięcia handlu. Strefa wolnego handlu w ramach Transatlantyckiego Partnerstwa w dziedzinie handlu i inwestycji będzie wyjątkiem od art. I GATT z 1994 r. Państwa tworzące strefy wolnego handlu lub unie celne przyznając preferencyjny dostępu do rynku partnerom handlowym, naruszają KNU, dyskryminując kraje trzecie pozostające poza ugrupowaniem integracyjnym.

Przeprowadzone badania naukowe potwierdzają tezę, iż utworzenie strefy wolnego handlu w stosunkach transatlantyckich doprowadzi do powstania efektu przesunięcia handlu. Import z krajów BRICS zastąpi przywóz towarów ze Stanów Zjednoczonych. Wystąpienie efektu przesunięcia handlu pogłębi różnice w kosztach handlowych między członkami TTIP a krajami trzecimi, w szczególności BRICS. Efekt przesunięcia dotknie partnerów handlowych Unii Europejskiej z krajów rozwijających, w tym kraje Maghrebu (Maroko, Tunezję, Algierię, Egipt) oraz Rosję i Białoruś' ${ }^{18}$.

Utworzenie Transatlantyckiego Partnerstwa w dziedzinie handlu i inwestycji zwiększy obrót z krajami trzecimi oraz produkt krajowy brutto tych krajów o prawie $100 \mathrm{mld}_{\text {euro }}{ }^{19}$. Według badań przeprowadzonych przez instytut IFO dla Federalnego Ministerstwa Ekonomii powstanie TTIP doprowadzi do wzrostu globalnego

18 G. Felbermayr, B. Heid, S. Lehwald, Die Transatlantische Handels- und Investitionspartnerschaft (THIP) Wemnutzt ein transatlantisches Freihandelsabkommen?, Bertelsmann Stiftung, Kooperationspartner, ifo Institut - Leibniz Institut für Wirtschaftsforschung an der Universität München, Gütersloh 2013.

19 E. Schmieg, TTIP - Chancen und Risiken für Entwicklungsländer, Stiftung Wissenschaft und Politik Deutsches Institut für Internationale Politik und Sicherheit, SWP-Zeitschriftenschau 1, Berlin, August 2014. 
dobrobytu o 3,3\%. Kraje trzecie poniosą straty na skutek eliminacji taryf celnych w stosunkach transatlantyckich, w szczególności Wybrzeże Kości Słoniowej, Gwinea, Uganda, Tanzania i pozostałe z Afryki. Partnerzy handlowi Stanów Zjednoczonych, Meksyk, Kanada, Australia, Japonia mogą stracić na powstaniu TTIP ze względu na konkurencję ze strony towarów europejskich.

Część krajów rozwijających się o niskich dochodach nie poniesie strat z powodu utworzenia TTIP, ponieważ UE i USA nie mogą konkurować w grupie towarów przemysłowych (tekstylia, odzież, obuwie), na które istnieją wysokie stawki celne dla nieczłonków strefy wolnego handlu ${ }^{20}$.

Efekt przesunięcia handlu w wyniku utworzenia strefy wolnego handlu w ramach TTIP będzie dyskryminować kraje trzecie, dojdzie więc do osłabienia szans na zakończenie Rundy z Doha i kontynuację procesu liberalizacji handlu międzynarodowego.

\section{Główne tematy negocjacyjne w Transatlantyckim Partnerstwie w dziedzinie handlu i inwestycji a regulacje WTO}

Jedynie w niektórych dziedzinach stronom udało się złożyć wstępne propozycje w negocjacjach.

W handlu artykułami przemysłowymi liberalizacja ceł nie powoduje wielu problemów negocjacyjnych. Cła nie stanowią obecnie znaczącej roli w handlu międzynarodowym, jedynie na niektóre produkty obowiązują kominy taryfowe, na produkty wrażliwe powyżej 15\% dla krajów rozwiniętych. Występuje zjawisko eskalacji taryf ${ }^{21}$. Duże znaczenie w obrotach dwustronnych odgrywają bariery pozataryfowe. Wspólna decyzja USA i UE o eliminacji ceł na artykuły przemysłowe w umowie TTIP będzie korzystnie oddziaływać na uzgodnienie liberalizacji handlu międzynarodowego w ramach Rundy z Doha pod egidą WTO. Stany Zjednoczone i Unia Europejska mogą wykorzystać zniesienie ceł w ramach TTIP jako argument na rzecz liberalizacji handlu międzynarodowego, w szczególności z gospodarkami wschodzącymi.

\footnotetext{
20 J. Rollo, P. Holmes, S. Henson, M. Mendez Parra, S. Ollerenshaw, J. Lopez Gonzalez, X. Cirera, M. Sandi, Potential Effects of the Proposed Transatlantic Trade and Investment Partnership on Selected Developing Countries, CARIS, University of Sussex for the Department for International Development, Brighton 2013, online http://bit.ly/1dLk15e

21 Eskalacja taryf oznacza, iż wyższe cła stosowane są na półprodukty niż na surowce, jeszcze wyższe na produkty gotowe. Praktyka ta chroni przemysł przetwórczy krajów rozwiniętych i zniechęca do rozwoju działalności przetwórczej w krajach, z których pochodzą surowce.
} 
Protekcjonizm w rolnictwie Stanów Zjednoczonych i Unii Europejskiej jest jedną z najistotniejszych przeszkód w zakończeniu Rundy z Doha. Transatlantyckie Partnerstwo w dziedzinie handlu i inwestycji jest szansą na liberalizację handlu rolnego między USA i UE oraz złagodzenie protekcjonizmu między USA i UE, a następnie liberalizacji handlu rolnego na forum WTO w wymianie z pozostałymi protekcjonistycznymi państwami zarówno rozwiniętymi, jak i rozwijającymi się.

Unia Europejska i Stany Zjednoczone w TTIP ograniczyły jednak liberalizację handlu rolnego w porównaniu $\mathrm{z}$ Porozumieniem w sprawie rolnictwa WTO. W negocjacjach o TTIP uwzględniono jedynie liberalizację stawek celnych. UE i USA stosują wysoki protekcjonizm $\mathrm{w}$ rolnictwie $\mathrm{w}$ formie wsparcia wewnętrznego w ramach środków zielonej skrzynki (green box), dlatego USA i UE mogą w Umowie o Transatlantyckim Partnerstwie w dziedzinie handlu i inwestycji, zachowując protekcjonizm, negocjować obniżki ceł. Ewolucja zmiany form protekcjonizmu ze wsparcia cenowego na bezpośrednie, wymuszona negocjacjami Rundy z Doha, pozwala na liberalizację ceł bez pozbawienia producentów rolnych wysokich dochodów. Wsparcie w ramach środków zielonej skrzynki wzrosło z 16 mld USD w 2000 r. do 120 mld w 2011 r. w Stanach Zjednoczonych (rysunek 4) ${ }^{22}$, w Unii Europejskiej z 22 mld USD w 2000 r. do 68 mld USD w 2011 r. (rysunek 5). W obu przypadkach ograniczeniu uległo wsparcie krajowe (AMS), podlegające redukcji, zgodnie z regulacjami WTO ${ }^{23}$.

Porozumienie Rundy urugwajskiej w sprawie rolnictwa z 1994 r. przyniosło znaczną przejrzystość w stosowaniu narzędzi polityki handlowej UE-USA. Przyjęto zobowiązanie o obniżeniu poziomu ceł w okresie 6 lat od wejścia w życie postanowień Rundy urugwajskiej średnio o 36\% w krajach rozwiniętych oraz o $24 \%$ w krajach rozwijających się. Uregulowano również zakres liberalizacji oraz zastosowania środków polityki wewnętrznej kraju (wsparcia wewnętrznego), które zniekształcają wymianę handlową. Skomplikowany sposób katalogowania narzędzi wsparcia wewnętrznego ilustruje zainteresowanie krajów rozwiniętych, w szczególności Stanów Zjednoczonych i Unii Europejskiej, utrzymaniem protekcjonizmu w rolnictwie i niechęć do liberalizacji.

22 Według najnowszych danych WTO.

${ }^{23}$ Protekcjonizm UE do 1992 r. polegał na interwencjonizmie cenowym. Wysoki poziom cen interwencyjnych, znacznie wyższy od cen światowych, gwarantował osiąganie wysokich dochodów producentów rolnych, samowystarczalność w produkcji żywności oraz stabilizację rynków. Ochronę przed konkurencją zagraniczną umożliwiał wprowadzony wysoki poziom ceł oraz subsydia eksportowe, które zniekształcały wymianę międzynarodową. Protekcjonistyczna wspólna polityka rolna Unii Europejskiej, jednolita dla wszystkich krajów członkowskich, uniemożliwiała liberalizację handlu rolnego w kolejnych rundach GATT/WTO. Dopiero w ósmej rundzie wielostronnych negocjacji handlowych, nazwanej Rundą urugwajską, w niewielkim stopniu zliberalizowano handel rolny. 


\section{Rysunek 4. Wsparcie wewnętrzne w rolnictwie Stanów Zjednoczonych w latach 2000-2011 (w mld USD)}

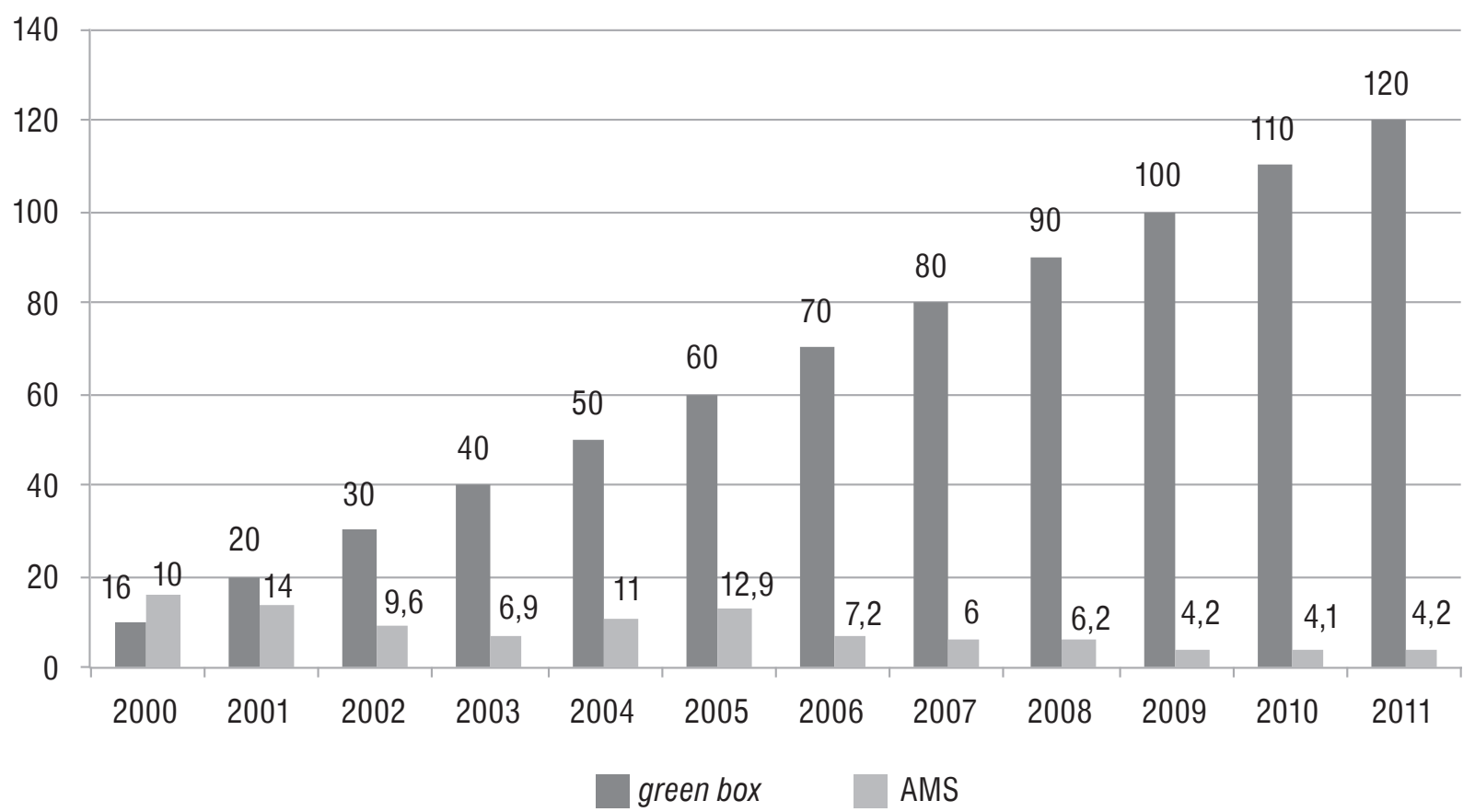

Źródło: Na podstawie danych notyfikowanych do WTO, www.wto.org

\section{Rysunek 5. Wsparcie wewnętrzne w rolnictwie Unii Europejskiej w latach 2000-2011} (w mld USD)

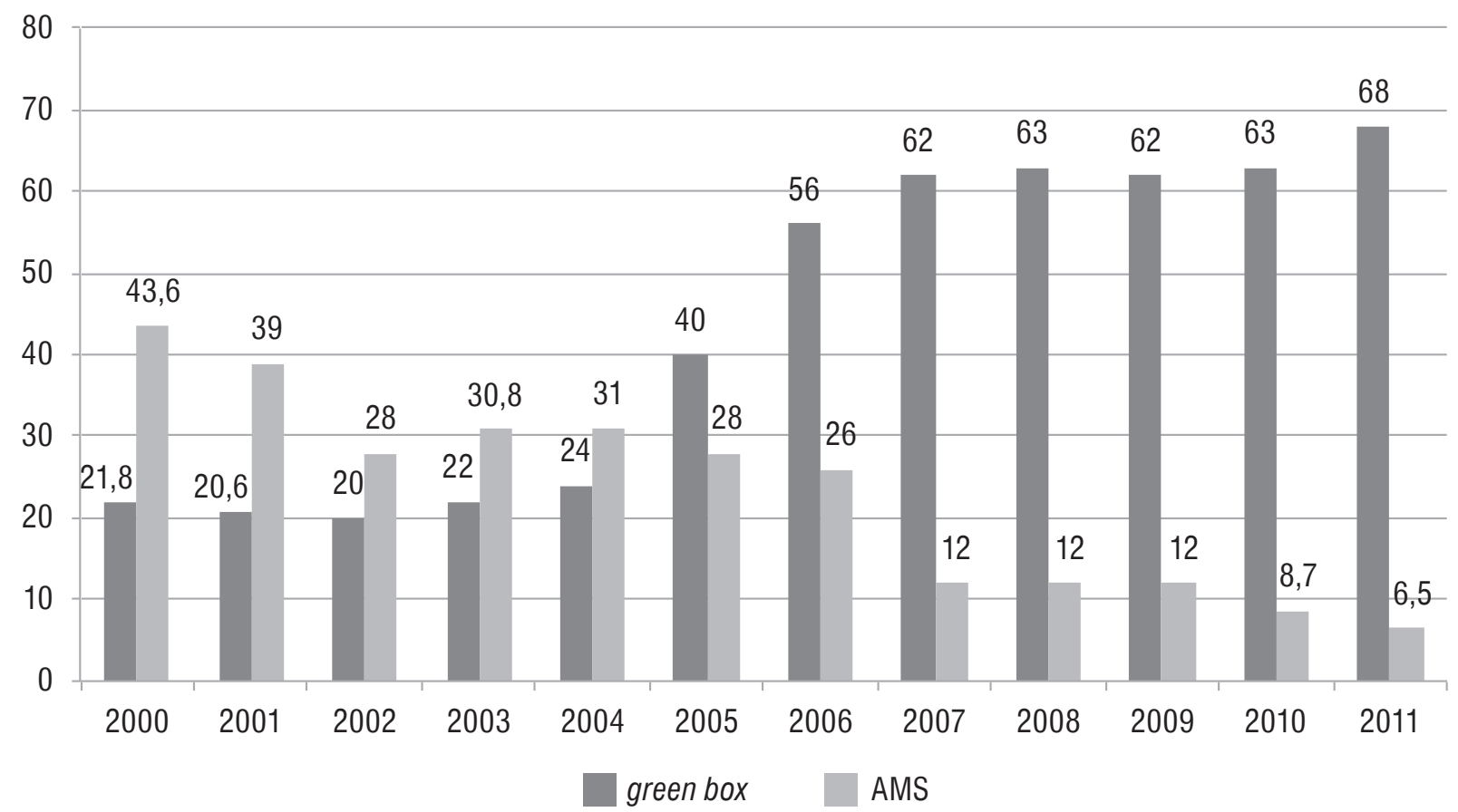

Źródło: Na podstawie danych notyfikowanych do WTO, www.wto.org 
Podział środków wsparcia wewnętrznego oparto na kolorach świateł w transporcie drogowym. I tak kolor czerwony oznaczał środki niedozwolone w wymianie handlowej; pomarańczowy - środki, które należy stopniowo ograniczać w handlu międzynarodowym; zielony - środki dozwolone, niepodlegające redukcji. Najbardziej protekcjonistyczne środki wsparcia ujęto w skrzynce pomarańczowej (amber box), należą do nich przede wszystkim ceny interwencyjne. Skrzynka zielona zawiera prawnie dopuszczalne środki WTO wsparcia handlu produktami rolnymi. Należą do nich: regionalne, społeczne oraz środowiskowe państwowe środki wsparcia oraz niezależne od produkcji płatności bezpośrednie. Uznano, iż środki skrzynki zielonej nie powodują zakłóceń w handlu międzynarodowym lub w produkcji. Wyklucza to stosowanie wsparcia cenowego lub dopłat bezpośrednich połączonych z wielkością produkcji ${ }^{24}$. Obok środków wyszczególnionych w skrzynce zielonej utworzono specjalną niebieską skrzynkę (blue box) - nową kategorię nieistniejącą w handlu produktami przemysłowymi ${ }^{25}$.

W Rundzie urugwajskiej zobowiązano również członków WTO do obniżenia wsparcia krajowego, na podstawie tzw. zagregowanego wskaźnika wsparcia (aggregate measurement of support, AMS), o 20\% w okresie 6 lat w stosunku do okresu bazowego (lata 1986-1988), w którym kraje rozwinięte stosowały najwyższy poziom subwencji.

Pod wpływem czynników zewnętrznych, wielostronnych negocjacji Rundy urugwajskiej w latach 90. XX w. i Rundy z Doha, trwającej od 2001 r., Unia Europejska zreformowała wspólną politykę rolną. Obniżeniu uległ poziom cen interwencyjnych, a utracone dochody producentów rolnych zrekompensowano za pomocą płatności bezpośrednich, ustanowionych w reformie McSharry’ego z 1992 r., uzależnionych od produkcji. Na podstawie reform z lat 2003 oraz 2008 Unia Europejska wprowadziła nowy system płatności bezpośrednich, uniezależnionych od produkcji, związany ze zrównoważonym rozwojem rolnictwa. Płatności bezpośrednie uniezależnione od produkcji producentów rolnych należące do środków wsparcia wewnętrznego, w tzw. skrzynce zielonej (green box), nie podlegają redukcji. Tak więc kraje rozwinięte zmieniły formę interwencjonizmu, ograniczyły wsparcie cenowe na rzecz

${ }^{24}$ Do środków skrzynki zielonej należą strukturalne programy dostosowawcze, pomoc państwa w zakresie bezpieczeństwa żywnościowego, uniezależnione od produkcji wsparcie dochodów, pomoc finansowa wypłacana w związku z katastrofami naturalnymi i badawczymi.

${ }^{25}$ Skrzynka niebieska, ustanowiona jako specjalna konstrukcja w Porozumieniu w sprawie rolnictwa, była wyrazem kompromisu między krajami rozwiniętymi i rozwijającymi się. Środki skrzynki niebieskiej ustanowiono pod naciskiem politycznym UE. W art. VI ust. 5 Porozumienia w sprawie rolnictwa znalazły się środki wsparcia wewnętrznego, które nie kwalifikowały się do amber box, a tym samym nie zakłócały znacząco handlu międzynarodowego. Kategoria ta miała pełnić rolę przejściową i zawierała typy wsparcia bezpośredniego stosowane wobec producentów objętych programami ograniczającymi produkcję (przypisane do wielkości obszaru lub hodowli, a nie wielkości produkcji). Wsparcie to nie podlegało redukcji, ale nie może wzrosnąć ponad poziom z $1992 \mathrm{r}$. 
płatności bezpośrednich, wybierając interwencjonizm wsparcia bezpośredniego, który w mniejszym stopniu zakłóca wymianę międzynarodową ${ }^{26}$. Wprowadzenie płatności bezpośrednich, uniezależnionych od produkcji, umożliwiło Unii Europejskiej wycofanie się z subsydiowania eksportu i udział w negocjowaniu liberalizacji barier celnych w Rundzie z Doha.

W polityce rolnej Unii Europejskiej oraz Stanów Zjednoczonych coraz większe znaczenie odgrywają elementy ochrony środowiskowej (ekologiczne), fitosanitarne, ochrony ludzi, zwierząt, życia lub roślin. Kwestie te stały się przedmiotem sporów handlowych między USA i UE. Obie strony wykorzystywały środki Porozumienia w sprawie stosowania środków sanitarnych i fitosanitarnych do celów protekcjonistycznych ${ }^{27}$, aby zminimalizować skutki redukcji wsparcia w ramach skrzynki niebieskiej (blue box) ${ }^{28}$. Podobnie jak w Unii Europejskiej, rolnictwo w Stanach Zjednoczonych podlega interwencjonizmowi za pomocą płatności bezpośrednich (direct payments) jako płatności obszarowych związanych z historycznymi wielkościami produkcji na danej powierzchni areału; płatności antycyklicznych (counter-cyclical payments), których wypłata związana jest $\mathrm{z}$ ustaleniem ceny docelowej wsparcia (target price), płatności te stanowią różnicę między ceną rynkową a docelową w przypadku obniżenia cen rynkowych ${ }^{29}$.

Zarówno UE, jak i USA posiadają konkurencyjne rolnictwo. Utworzenie TTIP doprowadzi do dalszej restrukturyzacji firm przetwórczych po obu stronach Atlantyku.

\footnotetext{
26 Płatności bezpośrednie uniezależnione od produkcji, czyli od obowiązku prowadzenia działalności gospodarczej, dla producentów wytwarzających na rynek będą stanowić źródło dofinansowania dochodów wydatków na rozwój gospodarstw rolnych. Dla producentów rolnych wyłącznie z nazwy, niemających styczności z rynkiem płatności bezpośrednie są źródłem dochodów za utrzymanie ziemi w dobrej kulturze, poza tym ta grupa rolników nie jest zobowiązana do wydatkowania płatności bezpośrednich na określone cele. Tak więc środki te rolnicy mogą rozdysponować na konsumpcję.

${ }^{27} \mathrm{~W}$ Porozumieniu w sprawie stosowania środków sanitarnych i fitosanitarnych określono uprawnienia państw do zastosowania środków ochronnych rynku krajowego w celu ochrony życia lub zdrowia ludzi, zwierząt lub roślin. Państwa członkowskie stosując środki sanitarne i fitosanitarne, nie mogą powodować nieuzasadnionej dyskryminacji między członkami WTO, ponieważ stanowiłby ukryte ograniczenie w handlu międzynarodowym. Por. Obwieszczenie Ministra Spraw Zagranicznych z dnia 4 grudnia 1995 r. w sprawie publikacji załączników do Porozumienia ustanawiającego Światową Organizację Handlu (WTO), DzU 1996.9.54.

28 Płatności bezpośrednie w ramach systemów ograniczania produkcji nie będą podlegały zobowiązaniom redukcji wsparcia wewnętrznego, jeżeli: (i) takie płatności są oparte na ustalonych rozmiarach gruntów i zbiorów lub (ii) takie płatności są dokonywane w odniesieniu do co najwyżej 85\% wyjściowego poziomu produkcji; lub (iii) płatności dotyczące zwierząt hodowlanych są oparte na określonym, stałym pogłowiu. Wyłączenie płatności bezpośrednich ze zobowiązań redukcyjnych spełniające powyższe kryteria będzie wyrażone w postaci wyłączeń wartości tych płatności bezpośrednich z kalkulacji bieżącego łącznego AMS dotyczącej członka. Por. art. 6.5 Porozumienia w sprawie rolnictwa, Obwieszczenie Ministra Spraw Zagranicznych z dnia 4 grudnia 1995 r. w sprawie publikacji załączników do Porozumienia ustanawiającego Światową Organizację Handlu (WTO), ibidem.

${ }^{29} \mathrm{Na}$ temat ewolucji polityki rolnej Stanów Zjednoczonych patrz: OECD, Evaluation of Agricultural Policy Reforms in the United States, OECD, Paris 2011.
} 
HLWG zaleciał Stanom Zjednoczonym i Unii Europejskiej stworzenie w umowie punktu SPS+ oraz poprawy dwustronnych relacji w rozwiązywaniu sporów w regulacjach sanitarnych i fitosanitarnych. Postanowienia w umowie o TTIP dotyczące środków sanitarnych i fitosanitarnych będą opierały się na regulacjach Porozumienia w sprawie stosowania środków sanitarnych i fitosanitarnych w WTO.

Według niektórych badań standaryzacja przepisów sanitarnych i fitosanitarnych może w przyszłości zmniejszyć koszty handlowe dla krajów członkowskich TTIP oraz krajów trzecich ${ }^{30}$.W dotychczasowych stosunkach handlowych Unia Europejska nie zdecydowała się na obniżenie standardów sanitarnych w porozumieniu z Kanadą (Umowa o partnerstwie i wolnym handlu, The Comprehensive Trade and Economic Agreement, CETA). Podobnie w TTIP, Unia Europejska nie zdecyduje się na zmianę europejskich norm.

Zagadnienia dotyczące środków sanitarnych i fitosanitarnych (SPS) odgrywają duże znaczenie $\mathrm{w}$ handlu rolnym, ponieważ przeciwdziałają chorobom zwierząt i roślin, z których wytwarzana jest żywność. Stany Zjednoczone są zwolennikami oparcia uregulowań w tym zakresie w TTIP na „podejściu naukowym”, które prowadziło do wielu wojen handlowych między UE a USA w dziedzinie środków sanitarnych i fitosanitarnych. Trwający od 1988 r. spór handlowy w sprawie importu wołowiny z hormonem wzrostu ze Stanów Zjednoczonych objął pod koniec lat 90. $\mathrm{XX}$ w. również produkty przemysłowe, na które USA w odwecie podniosły taryfy celne. Wojny handlowe prowadziły do zamykania rynku europejskiego na eksport mięsa drobiowego ze Stanów Zjednoczonych ${ }^{31}$.

Unia Europejska nie zgadza się na przyjęcie w TTIP niektórych regulacji „wrażliwych społecznie" dotyczących żywności modyfikowanej genetycznie. W Unii Europejskiej istnieją odpowiednie uregulowania, które zakazują wprowadzania do obrotu żywności zagrażającej życiu konsumentów, regulacje w tej dziedzinie egzekwuje Europejski Urząd ds. Bezpieczeństwa Żywności. W pozostałych kwestiach dotyczące obrotu handlowego żywności Transatlantyckie Partnerstwo w dziedzinie handlu i inwestycji stwarza szanse na stworzenie wysokich standardów ochrony konsumentów.

Niektóre zagadnienia, takie jak liberalizacja przepływu usług, ochrony własności intelektualnej oraz zamówień publicznych, wykraczają poza postanowienia wielostronnych porozumień międzynarodowych WTO. TTIP tworzy szansę na zbliżenie stanowisk głównych potęg handlowych USA i UE oraz zaangażowanie zainteresowanych liberalizacją tych dziedzin do zakończenia Rundy z Doha. Utworzenie

30 J. Rollo et al., op.cit.

31 J.J. Schott, C. Cimino, Crafting a Transatlantic Trade and Investment Partnership: What Can be Done, Policy Brief No. PB13-8, Peterson Institute for International Economics, Washington, March 2013. 
TTIP stwarza możliwość uwzględnienia tych zagadnień jeszcze w Rundzie z Doha lub w przyszłych wielostronnych negocjacjach w przypadku fiaska obecnej rundy.

W dziedzinie usług Stany Zjednoczone preferują liberalizację według tzw. listy negatywnej, a więc wszystkich rodzajów usług z pewnymi wyjątkami, natomiast Unia Europejska zainteresowana jest liberalizacją według tzw. listy pozytywnej, wybranych subsektorów usług. Unia Europejska w dotychczasowych umowach o wolnym handlu nie zastosowała listy negatywnej w procesie otwierania rynku usług. Zasada powszechnego zobowiązania (single undertaking) utrudnia liberalizację usług w ramach Rundy z Doha, dlatego w 2012 r. powstała wspólna inicjatywa krajów rozwijających się i rozwiniętych utworzenia kilkustronnego Porozumienia w sprawie usług (International Services Agreement). Grupa takich państw jak: Australia, Kanada, Chile, Kolumbia, Kostaryka, Unia Europejska, Hongkong, Izrael, Japonia, Meksyk, Nowa Zelandia, Norwegia, Pakistan, Peru, Singapur, Korea Płd., Szwajcaria, Tajwan, Turcja, Stany Zjednoczone podjęła inicjatywę utworzenia poza negocjacjami Rundy z Doha porozumienia dla państw zainteresowanych dalszą liberalizacją usług międzynarodowych $^{32}$. W negocjacjach o TTIP Stany Zjednoczone i Unia Europejska mogą uzgodnić podejście hybrydowe polegające na połączeniu listy negatywnej i pozytywnej liberalizacji usług. Po światowym kryzysie dla obu stron istotnym zadaniem będzie liberalizacja usług finansowych.

Stany Zjednoczone i Unia Europejska w TTIP rozszerzyły ochronę własności intelektualnej w porównaniu z Porozumieniem TRIPS. Oznaczenia geograficzne należą do priorytetów negocjacyjnych Unii Europejskiej do zwiększenia ochrony produktów spożywczych i surowców rolnych (wino, sery, szynki). USA i UE posiadały zróżnicowane przepisy o ochronie oznaczeń geograficznych. Stany Zjednoczone są zwolennikami dobrowolnych oznaczeń geograficznych. Wymiana towarowa związana z ochroną oznaczeń geograficznych, uregulowanych w WTO w Porozumieniu o TRIPS, w różny sposób jest interpretowana przez Stany Zjednoczone i Unię Europejską. W USA oznaczenia geograficzne intepretowano jako przejaw zwiększenia konkurencji, w UE - jako informacje niezbędne dla ochrony konsumentów. Największe spory wzbudza kwestia oznakowania win, serów, napojów, owoców, produktów mięsnych. UE wnioskuje o lepszą ochronę oznaczeń geograficznych na rynku amerykańskim.

W przypadku zamówień publicznych UE i USA są członkami kilkustronnego Porozumienia o zamówieniach rządowych (GPA), które weszło w życie w 1996 r., następnie zostało zmienione w kwietniu $2012 \mathrm{r}$. Stany Zjednoczone postulują przyjęcie

32 J.J. Schott, M. Lee, J. Muir, Prospects for Services Trade Negotiations, „Working Paper Series”, Peterson Institute for International Economics, Washington, October 2012. 
zobowiązań w kwestii dostępu do rynku na podstawie jedynie części wymagań w porównaniu z GPA. Unia Europejska jest zwolennikiem przyjęcia szerszego otwarcia rynku zamówień publicznych. Jak wynika $z$ badań CEPR w Londynie, otwarcie rynku zamówień publicznych w Stanach Zjednoczonych będzie oznaczać korzyści dla firm z UE (np. budowlanych), które zyskają prawo do udziału w przetargach na duże projekty w USA.

Zagadnienia liberalizacji usług, ochrony własności intelektualnej i zamówień publicznych nie stanowią kontrowersji społecznych, tak jak w przypadku inwestycji.

Przepływ inwestycji jest w niewielkim stopniu uregulowany przez WTO. Unia Europejska i USA próbowała włączyć tematykę inwestycji do wielostronnych negocjacji handlowych w Rundzie z Doha ${ }^{33}$. Z inicjatywy krajów rozwiniętych inwestycje stały się jedną z kwestii singapurskich (obok zamówień publicznych, konkurencji i ułatwień w handlu), jednak sprzeciw krajów rozwijających się doprowadził do jej usunięcia w 2003 r. na Konferencji ministerialnej w Cancun ${ }^{34}$. Uregulowanie inwestycji w TTIP stworzyłoby możliwość wypracowania transatlantyckiego modelu światowych rozwiązań w tej kwestii w WTO.

Stany Zjednoczone i Unię Europejską cechuje duży stopień otwarcia gospodarek na przepływy inwestycji. Stany Zjednoczone są najważniejszym państwem lokującym bezpośrednie inwestycje zagraniczne w Unii Europejskiej na poziomie 39\% w $2012 \mathrm{r}$. Stany Zjednoczone należą do najważniejszych krajów, w których Unia Europejska lokuje swoje bezpośrednie inwestycje zagraniczne (37\% w 2012 r.).

Przepływ bezpośrednich inwestycji zagranicznych z racji przeniesienia własności spółek do innego państwa wymaga ochrony inwestorów. Ochrona inwestycji oraz system rozstrzygania sporów między państwem a firmą zagraniczną otwierają dla UE i USA perspektywy przepływu kapitału w formie bezpośrednich inwestycji zagranicznych.

Wiele kontrowersji w negocjowanej umowie o TTIP dotyczy rozstrzygania sporów między inwestorem zagranicznym a państwem przyjmującym (Investor-to-State Dispute Settlement, ISDS). We współczesnej gospodarce światowej spory między inwestorem a państwem przyjmującym powstały na tle zmian regulacji prawnych w polityce publicznej państwa przyjmującego.

Występuje ogromne ryzyko tzw. chłodzenia regulacji (chilling effect), ponieważ rządy państw, będąc pod naciskiem inwestorów i groźby wniesienia skargi przed

${ }^{33}$ W. Dugiel, Światowy system handlu. Nowe wyzwania i próby reform, Oficyna Wydawnicza SGH, Warszawa 2013.

34 S. Woolcock, European Union Policy on Foreign Investment: A Missed Opportunity?, w: Trade Liberalisationand Standardisation - New Directions in the 'Low Politics' of EU Foreign Policy, red. M. Cremona, T. Takács, Academy of European Law, European University Institute, Badia Fiesolana 2014/1. 
trybunał arbitrażowy, zrezygnują z przyjęcia zmian w polityce publicznej. Zjawisko "chłodzenia regulacji” oznacza, iż państwa nie mogą swobodnie zmieniać polityki publicznej, w zakresie ochrony środowiska, zdrowia, ponieważ obawiają się wniesienia pozwów przeciwko państwu przyjmującemu. Zmiany w polityce ochrony środowiska, zdrowia państwa przyjmującego inwestorzy uznali w sporach inwestor-państwo jako pośrednie lub inaczej de facto wywłaszczenie ${ }^{35}$.

W przypadku wystąpienia pośredniego lub de facto wywłaszczenia ${ }^{36}$ powołanie arbitrażu umożliwia zagranicznym inwestorom „państwa przyjmującego” rzetelne rozpatrzenie sporu przez arbitraż międzynarodowy oraz wypłatę odszkodowań.

Oponenci umieszczenia punktu o rozstrzyganiu sporów inwestor-państwo w TTIP argumentują, iż firmy zagraniczne korzystały z arbitrażu międzynarodowego przeciwko państwom przyjmującym, zmieniającym regulacje polityki publicznej37. Chodzi o skargę szwedzkiej grupy energetycznej Vattenfall z Niemcami (z powodu wycofania się Niemiec z polityki jądrowej) ${ }^{38}$, firmy tytoniowej Philip Morris przeciwko Australii ${ }^{39}$ oraz firm Corn Products International, ADM/Tate\&Lyle i Cargill ze Stanów Zjednoczonych przeciwko Meksykowi. Wielonarodowe koncerny, stosując definicję de facto wywłaszczenia do zmian regulacji prawnych polityki publicznej rządu państwa przyjmującego, zażądały w kolejnych sporach odszkodowań za pośrednie wywłaszczenie.

Jednym z ostatnich sporów inwestycyjnych, dotychczas nierozstrzygniętych, na które powołują się organizacje międzyrządowe oraz parlamentarzyści w państwach członkowskich Unii Europejskiej, okazał się pozew firmy Vattenfall ze Szwecji przeciwko rządowi Niemiec. Po katastrofie w Fukushimie w Japonii w 2011 r. Niemcy zmieniły politykę w dziedzinie energetyki jądrowej. W 2011 r. znowelizowano ustawę o energii atomowej (Atomic Energy Act) ${ }^{40}$, państwo wycofało się z wykorzystania energetyki jądrowej w gospodarce do 2022 r. Decyzja rządu Niemiec okazała się niekorzystna dla koncernów energetycznych, które w zakresie wykorzystania energii

${ }^{35} \mathrm{~W}$. Hummer, Investitionsschutz in der geplanten „Transatlantischen Handels- und Investitionspartnerschaft" (TTIP) zwischen der EU und den USA, EU-Infothek, Wien, 6.05.2014.

36 Pojęcia pośrednie wywłaszczenie i de facto wywłaszczenie uznaje się w literaturze jako synonimy.

${ }^{37}$ Nowo mianowana komisarz ds. handlu Cecilia Malmstrom uznała, iż punkt w Transatlantyckim Partnerstwie w dziedzinie handlu i inwestycji dotyczący prawa firm zagranicznych do pozywania państwa jest jak „broń jądrowa” i powinien być usunięty z planowanej umowy. Por. J. Kanter, Cecilia Malmstrom, E.U. Trade Nominee, Points to 'Toxic Element' in U.S. Talks, „The New York Times” September 29, 2014.

${ }^{38}$ How to lose half a trillion euros, "The Economist" October 12, 2013.

39 Philip Morris Sues Australia Over Cigarette Packaging by Bloomberg News, „The New York Times” June 26, 2011.

40 Por. 13. AtGÄndG v. 31.07.2011, BGBl I S. 1704 (No. 43), poprawka do Atomic Energy Act, weszła w życie 6.08.2011 r.; N. Bernasconi-Osterwalder, R.T. Hoffmann, The German Nuclear Phase-Out Put to the Test in International Investment Arbitration? Background to the new dispute Vattenfall v. Germany (II), The International Institute for Sustainable Development, Winnipeg, June 2012. 
atomowej zaplanowały długoterminową działalność gospodarczą. Koncern ze Szwecji, jako właściciel jednej z 17 elektrowni jądrowych w Niemczech, po kilku miesiącach od ustanowienia regulacji prawnych w Niemczech złożył pozew do ICSID (Międzynarodowego Centrum Rozstrzygania Sporów Inwestycyjnych w ramach Banku Światowego) w Waszyngtonie ${ }^{41}$ i zażądał odszkodowania ${ }^{42} \mathrm{w}$ wysokości 3,7 mld euro $\left(4,7\right.$ mld USD) za wycofanie państwa z polityki wykorzystania energii jądrowej ${ }^{43}$.

Kolejny spór przywoływany przez oponentów uwzględnienia ochrony inwestycji w TTIP pomiędzy firmą Philip Morris a Australią dotyczył opakowań detalicznych artykułów tytoniowych.

Parlament Australii w dniu 21 listopada 2011 r. przyjął restrykcyjne z punktu widzenia producentów i dystrybutorów przepisy w sprawie opakowań papierosów. Wprowadzone w Australii rygorystyczne przepisy zakazywały drukowania logo firmy, zezwalały na wydruk nazwy danego gatunku papierosów wyłącznie niewielkim drukiem. Szarobure opakowania miały wzbudzać niechęć konsumentów do zakupu papierosów. Obrazy graficzne owrzodzenia jamy ustnej, nowotworowych płuc i zgorzel kończyn zdominowały opakowanie na paczkach papierosów sprzedawanych w Australii ${ }^{44}$. Koncerny tytoniowe British American Tobacco, Imperial Tobacco, Japan Tobacco oraz Philip Morris Australia uznały, iż zakaz publikowania logo marki naruszał ich własność intelektualną. Wobec zaistniałej sytuacji firma Philip Morris Asia (PMA) wniosła roszczenia przeciwko Australii w ramach obowiązującego oba kraje dwustronnego traktatu inwestycyjnego (Australia-Hongkong Bilateral Investment Treaty, BIT), podpisanego w $1993 \mathrm{r}^{45}$ Sąd Najwyższy Australii rozpatrzywszy spór w sprawie naruszenia praw inwestorów zagranicznych, uznał, iż nie istnieją wiarygodne dowody na zmniejszenie liczby palaczy po ujednoliceniu opakowań papierosó $w^{46}$, orzekając, iż obowiązująca od 1 grudnia 2012 r. ustawa dotycząca etykietowania opakowań detalicznych wyrobów tytoniowych nie narusza konstytucji.

Niezadowolona z wyroku Sądu Najwyższego firma PMA wystąpiła o zwołanie trybunału arbitrażowego o zawieszeniu środka prawnego przez Australię oraz znaczną rekompensatę za szkody finansowe. Arbitraż przebiegał zgodnie z postanowieniami dwustronnej umowy inwestycyjnej (BIT) oraz Regulaminem Arbitrażowym Komisji

${ }^{41}$ ICSID Case No. ARB/12/12.

42 The arbitration game. Governments are souring on treaties to protect foreign investors, „The Economist” October 11, 2014.

${ }^{43}$ Spór zarejestrowano 31 maja $2012 \mathrm{r}$.

${ }^{44}$ M. Siegel, Australian Court Strikes Down Tobacco Challenge, „The New York Times” August 15, 2012.

${ }^{45}$ Australia podpisała 20 dwustronnych umów inwestycyjnych, które gwarantowały ochronę marki, własności intelektualnej.

${ }^{46}$ Philip Morris komentuje ujednolicenie opakowań papierosów w Australii, Philip Morris Limited/SIZ PAP, 16.08.2012; Philip Morris opuszcza Australię, 4.04.2014. 
Narodów Zjednoczonych ds. Międzynarodowego Prawa Handlowego 2010 (UNCITRAL). Zarówno firma PMA, jak i rząd Australii wyznaczyli po jednym arbitrze ${ }^{47}$. Powołany trybunał arbitrażowy najpóźniej do 2017 r. powinien rozstrzygnąć spór ${ }^{48}$. Unia Europejska, negocjując Transatlantyckie Partnerstwo w dziedzinie handlu i inwestycji, obawia się zagrożenia dla suwerenności państwa. Rozmaite spory w NAFTA inwestor-państwo zainicjowane przez USA z powodu zmiany uregulowań polityki ochrony środowiska oraz zdrowia publicznego ograniczyły suwerenne stanowienie polityki publicznej państwa członków NAFTA.

Firmy ze Stanów Zjednoczonych: Corn Products International, ADM/Tate\&Lylei Cargill pozwały rząd Meksyku, powołując się na zasady określone w NAFTA, dotyczące ustanowienia barier handlowych na import syropu kukurydzianego o wysokiej zawartości fruktozy (ramka 2) ${ }^{49}$.

\title{
Ramka 2. Charakterystyka sporów inwestycyjnych w NAFTA
}

\begin{abstract}
Meksyk prowadzit politykę interwencjonizmu w rolnictwie, w szczególności w produkcji cukrua, nie dopuszczając za pomocą systemu kar do nadprodukcji oraz przekroczenia kwot eksportowych. Postanowienia NAFTA zmienily możliwości regulowania polityki rolnej państw członkowskich (USA, Kanady i Meksyku), wprowadzono bezcłowe kontyngenty taryfowe na import cukru do Stanów Zjednoczonych z Kanady i Meksyku na okres 15 lat (do 2008 r.). Tak więc Stany Zjednoczone otworzyły swój rynek na nadwyżki cukru eksportowane przez Meksyk. Jednak w przepisach wykonawczych do porozumienia NAFTA USA wprowadziły szeroką definicję cukru pochodzącego z Meksyku, określając tą nazwą również syrop kukurydziany o wysokiej zawartości fruktozy (high fructose corn syrup, HFCS).

W 1996 r. Meksyk zamierzał wyeksportować krajowe nadwyżki cukru do Stanów Zjednoczonych, w myśl regulacji w porozumieniu NAFTA. Jednak bezcłowy import cukru został zablokowany przez Stany Zjednoczone. Meksyk zażądał zwołania panelu rozstrzygania sporów na mocy porozumienia NAFTA, jednak Stany Zjednoczone odmówiły wyznaczenia sędziów do panelu. Poza tym Stany Zjednoczone nadal eksportowały duże ilości wysoko dotowanego HFCS na meksykański rynek. W 1997 r. rząd meksykański nałożył cła antydumpingowe na HFCS importowany ze Stanów Zjednoczonych, w związku ze sprzedażą tego produktu poniżej kosztów produkcji. Po wejściu w życie przepisów NAFTA napływ amerykańskiego HFCS znacznie ograniczył sprzedaż meksykańskiego cukru, powodując utratę miejsc pracy w tym sektorze. Cukrownie musiały dokonać przymusowych wypłat dla plantatorów trzciny cukrowej po cenach ustanowionych przez rząd. Po przymusowym skupie trzciny cukrowej cukrownie znalazły się na granicy wypłacalności.

We wrześniu 2001 r. Meksyk wywłaszczył 27 zadłużonych młynów, w tym 5 posiadanych przez meksykańską firmę GAMb (Grupo Azucarero México, SA de CV), w której udziały (14,1\%) posiadała amerykańska spółka GAMI Investments, Inc, z siedzibą w Las Vegas z Nevady, aby odzyskać ogromny dług i zapewnić wypłaty wynagrodzeń dla pracowników. Ponadto Kongres Meksyku uchwalił federalny podatek od luksusu do budżetu na 2001 r., w tym 20\% podatku na napoje i syropy, do których produkcji użyto substancji słodzących innych niż cukier trzcinowy. Wprowadzony podatek skutecznie zablokował import amerykańskiego HFCS i ograniczył produkcje w zakładach HFCS w Meksyku. W 2004 r. Stany Zjednoczone groziły podatkami odwetowymi, którymi miała być objęta tequila i inne produkty żywnościowe. Amerykańska firma GAMI wniosła do UNCITRAL pozew przeciwko Meksykowi w dniu 9 kwietnia 2002 r. Firma GAMI twierdziła, że regulacje wprowadzone przez Meksyk doprowadzity do strat młynów w okresie 3 lat od daty wywłaszczenia w 2001 r. Inwestor ze Stanów Zjednoczonych (firma GAMI) uzasadniał, iż działania Meksyku naruszyły art. 1102 Porozumienia NAFTA (traktowanie narodowe), art. 1105 (sprawiedliwe i równe traktowanie) oraz art. 1110 (wywłaszczenie). Firma GAMI postulowała o wypłate $55 \mathrm{mln}$ USD odszkodowania.
\end{abstract}

${ }^{47}$ Firma PMA mianowała profesor Gabrielle Kaufmann-Kohler, obywatelkę Szwajcarii. Australia mianowała profesora Donalda McRae, podwójnego obywatela Nowej Zelandii i Kanady.

${ }^{48} \mathrm{Na}$ podstawie informacji Philip Morris International, dostępnych na stronie firmy, 21.10.2014, http:// www.pmi.com/eng/media_center/company_statements/Pages/bilateral_investment_treaty.aspx\#

49 E. Malkin, In Mexico, Sugar vs. U.S. Corn Syrup, „The New York Times” June 9, 2004. 
Zmiany w polityce publicznej Meksyku dotknęły również inne firmy ze Stanów Zjednoczonych. Firma Corn Products International (CPI), produkująca w Stanach Zjednoczonych syrop kukurydziany o wysokiej zawartości fruktozy (HFCS), zakwestionowała podatek rządu nakładany na napoje słodzone z HFCS (tj.napoje bezalkoholowe), niesłodzone z cukru trzcinowego. Meksyk argumentował, że podatek na HFCS, który utrudnia eksport z USA do Meksyku, był uzasadniony z powodu odmowy otwarcia rynku Stanów Zjednoczonych na import cukru trzcinowego, tak jak przewidziano w porozumieniu NAFTA. Firma Corn Products International ${ }^{c}$ w październiku $2003 \mathrm{r}$. wniosła pozew do ICSID, powołując się na rozdział 11 NAFTA w sprawie sporów inwestorpaństwo. Firma Corn Products International twierdziła, iż podatek na HFCS wprowadzony przez Meksyk naruszał zasadę traktowania narodowego inwestorów zagranicznych w NAFTA (art. 1102) i zakaz pośredniego wywłaszczenia w NAFTA (art. 1110). Firma Corn Products International domagała się odszkodowania przekraczającego $325 \mathrm{mln}$ USD. Firma wygrała spór, otrzymując 58,4 mln USD odszkodowania.

ADM, największy producent rolny na świecie, wytwarzający HFCS, oraz spółka AE Staley, zależna w całości od brytyjskiego koncernu Tate\&Lyle, wytwarzająca w Stanach Zjednoczonych HFCS, powołując się na NAFTA, wniosły w dniu 13 października 2003r. roszczenia inwestor-państwo do ICSID. Firma uznała, że podatek na HFCS narusza zobowiązania traktowania narodowego Meksyku w NAFTA (art. 1102), starając się o odszkodowanie w wysokości około 100 mln USD. ADM wygrało 37 mln USD odszkodowania.

a Produkcja i sprzedaż cukru stała się przedmiotem wielu przepisów prawa w interesie publicznym. Przemysł cukrowniczy w Meksyku był zarządzany przez trójstronne komisje pracowników, właścicieli młynów oraz rządu, które podejmowały działania w celu utrzymania wysokich cen na rynku krajowym.

${ }^{\mathrm{b}}$ Zbieżność nazw GAM i GAMI jest zupełnie przypadkowa.

${ }^{c}$ Corn Products International, Inc, z siedzibą w Westchester, w stanie Illinois, jest wiodącym na świecie producentem substancji słodzących i skrobi z kukurydzy w procesie rafinacji, w tym syropu kukurydzianego o wysokiej zawartości fruktozy (high fructose corn syrup, HFCS).

Źródło: Na podstawie: CITIZEN, http://www.citizen.org/documents/NAFTAReport_, Table of foreign investor-state cases and claims under NAFTA and other U.S. „trade” deals.

Zagraniczni inwestorzy podlegają ochronie zagwarantowanej przez (1) powszechne zasady międzynarodowego prawa państw obcych w ramach ochrony dyplomatycznej, jak również (2) dwustronne umowy o ochronie inwestycji (BIT-y), zawierane między krajem pochodzenia inwestycji a „państwem przyjmującym”, w którym przedsiębiorca zamierza prowadzić działalność gospodarczą oraz (3) międzynarodowe umowy inwestycyjne (IIAs); wreszcie (4) instytucje ponadnarodowe ${ }^{50}$.

Międzynarodową ochronę inwestycji stanowią wielopoziomowe źródła prawa, międzynarodowego oraz krajowego. Przykładem wielopoziomowego wykorzystania źródeł prawa są klauzule parasolowe (umbrella clauses) ${ }^{51}$, na których podstawie państwo przyjmujące gwarantuje przestrzeganie zobowiązań danych inwestorowi

${ }^{50}$ Międzynarodowe umowy IIAs “ (nie-BIT-y) można podzielić na trzy grupy umów: do pierwszej należą umowy przypominające postanowieniami BIT-y, w umowach tych zawarto rozdziały o obowiązkach inwestorów i państwa przyjmującego (np. umowy o wolnym handlu, współpracy gospodarczej). W drugiej grupie znalazły się umowy z regulacjami prawnymi dotyczącymi udzielania dostępu do rynku dla zagranicznych inwestorów, bez przepisów o ochronie inwestycji. Trzecia grupa dotyczy wyłącznie współpracy inwestycyjnej, która może obejmować inwestycje działania promocyjne lub wynegocjowanie przyszłych zobowiązań inwestycyjnych. Wyłącznie w pierwszej grupie IIAs znajdują się uregulowania rozstrzygania sporów między inwestorami a państwem przyjmującym. Por. UNCTAD, Investor-State Dispute Settlement, UNCTAD Series on Issues in International Investment Agreements II, United Nations Conference On Trade And Development, United Nations, New York, Geneva 2014.

51 W BIT-ach umieszczono klauzulę parasolową, która posiada wpływ na zastosowanie prawa krajowego w międzynarodowych sporach inwestycyjnych, w zakresie decydowania pomiędzy jurysdykcją sądów krajowych lub międzynarodowych trybunałów arbitrażowych. Klauzula parasolowa zabezpiecza nienaruszanie zobowiązań przyjętych przez państwo gospodarza wobec inwestora. 
(np. w umowach inwestor-państwo). Państwo przyjmujące ponosi odpowiedzialność w stosunkach cywilnoprawnych w przypadku nienależytego wywiązania się ze zobowiązań. W BIT-ach umieszczono klauzulę parasolową, która pozwala na wybór prawa krajowego w międzynarodowych sporach inwestycyjnych, w zakresie decydowania pomiędzy jurysdykcją sądów krajowych lub międzynarodowych trybunałów arbitrażowych. Klauzula parasolowa gwarantuje nienaruszanie zobowiązań przyjętych przez państwo gospodarza wobec inwestora.

W przypadku ochrony państw inwestorzy po wykorzystaniu krajowych środków odwoławczych w państwie przyjmującym mogą zażądać opieki dyplomatycznej państwa pochodzenia inwestora. Umowa o ochronie inwestycji między państwem pochodzenia inwestora a krajem przyjmującym (BITs) charakteryzuje się dostępem prawa krajowego państwa przyjmującego ${ }^{52}$. BIT-y pozwalają inwestorom, w przypadku naruszenia przyjętych w umowie norm związanych z inwestycją, pozwać (zaskarżyć) przed międzynarodowym trybunałem arbitrażowym państwo przyjmujące inwestycje o odszkodowa$n^{2}{ }^{53}$. W sporze między inwestorem a państwem przyjmującym nie uczestniczy państwo pochodzenia, ponieważ formalny partner umowy o ochronie inwestycji musiałby interweniować i uczestniczyć w międzynarodowym trybunale arbitrażowym ${ }^{54}$.

We współczesnej gospodarce światowej istnieje 3400 dwustronnych umów inwestycyjnych (BIT-y), z których 1400 podpisały państwa członkowskie UE - z nich 200 zawarto między państwami członkowskimi Unii Europejskiej, a 1200 z państwami trzecimi. Dwustronne umowy inwestycyjne zawarte przez Unię Europejską zawierają gwarancje ochrony inwestora zagranicznego ${ }^{55}$ :

1) ochrony przed dyskryminacją (klauzula największego uprzywilejowania i traktowania narodowego);

2) ochrony przed wywłaszczeniem, które nie zostało dokonane w interesie publicznym oraz zrekompensowane;

3) ochrony przed nieuczciwym i niesprawiedliwym traktowaniem, np. przez odmowę uczciwego procesu sądowego;

4) ochrony prawa do transferu zysków, jakie osiągają.

52 Inwestor i państwo przyjmujące inwestycję uzgadniają prawo krajowe jako właściwe do rozstrzygania sporów. Por. W. Hummer, op.cit.

53 Por. Umowy BIT to pełne bezpieczeństwo inwestycyjne, rozmowa K. Żaczkiewicz-Zborskiej z dr. Cezarym Wiśniewskim i dr. Marcinem Dziurdą z kancelarii Linklaters, 14.05.13, dostępna na stronie http://www. mediacje.lex.pl/czytaj/-/artykul/umowy-bit-to-pelne-bezpieczenstwo-inwestycyjne

${ }^{54} \mathrm{~W}$ niektórych BIT-ach duże znaczenie w rozstrzyganiu sporów inwestycyjnych odgrywa prawo krajowe. Część BIT-ów zawiera specjalne klauzule wyboru prawa krajowego do rozstrzygnięcia sporu inwestycyjnego, zawierają kombinację prawa międzynarodowego i wewnętrznego państw przyjmujących inwestycje. Por. P. Kosiński, Rola prawa krajowego w międzynarodowych sporach inwestycyjnych, „Studia Iuridica Toruniensia" t. VIII, Toruń 2011.

55 Por. W. Hummer, op.cit. 
Pierwszy BIT powstał w 1959 r. między Niemcami a Pakistanem. Ochrona inwestycji w podpisanych w latach 60 . XX w. BIT-ach polegała na ochronie przed wywłaszczeniem. Wszelkie spory inwestycyjne rozstrzygano na szczeblu międzyrządowym. W 1966 r. powołano Międzynarodowe Centrum Rozstrzygania Sporów Inwestycyjnych (International Center for Settlement of Investment Disputs, ICSID), wzmacniając słabą w tym okresie ochronę inwestorów zagranicznych ${ }^{56}$. Pod koniec lat 60 . XX w. przewidziano możliwość wnoszenia pozwów sądowych przez inwestorów przeciwko krajom przyjmującym inwestycje. Spory dotyczyły głównie odszkodowań z tytułu wywłaszczenia. Do końca lat 80 . XX w. nie istniał międzynarodowy arbitraż rozpatrujący spory między inwestorami a państwem przyjmującym. W okresie liberalizacji kapitału nastąpił gwałtowny wzrost liczby dwustronnych umów inwestycyjnych. Na początku lat 90. XX w. liczba BIT-ów nie przekraczała 400, dekadę później w 2001 r. liczba ta wyniosła 2099, natomiast w 2012 r. istniało na świecie prawie 3200 umów inwestycyjnych. Większość BIT-ów, a także inne międzynarodowe umowy inwestycyjne (IIAs) zawierają przepisy dotyczące rozstrzygania sporów między inwestorami a państwem przyjmującym przez międzynarodowy arbitraż. Proliferacja BIT-ów wynika ze słabo uregulowanych kwestii ochrony inwestycji na szczeblu międzynarodowym.

W dwustronnych umowach inwestycyjnych Unii Europejskiej nie występuje definicja de facto wywłaszczenia, forsowana przez Stany Zjednoczone w negocjacjach o TTIP, oraz nie ma zastosowania zasada "prawo do regulacji", które oznacza potwierdzenie prawa stron umowy inwestycyjnej do regulacji służących osiąganiu uzasadnionych celów polityki publicznej państwa ${ }^{57}$.

W sporach między inwestorem a państwem przyjmującym istotne znaczenie odgrywa definicja inwestycji, z której wynika ochrona prawna inwestorów. W niektórych umowach określono pojęcie inwestycji jedynie jako bezpośrednie inwestycje zagraniczne - BIZ, w innych umowach zawarto szerszą definicję, obejmującą wszystkie aktywa, czyli środki gospodarcze przedsiębiorstwa, w tym również własność intelektualną, prawa własności przemysłowej, know-how. Państwa członkowskie nie określiły szczegółowej definicji inwestycji ${ }^{58}$.

Różnice między rozwiązaniami w Stanach Zjednoczonych i Unii Europejskiej w sprawie dwustronnych umów inwestycyjnych (BIT-ów) dotyczą głównie kwestii definiowania wywłaszczenia.

${ }^{56}$ Ch. Tietje, op.cit.

57 Komisja Europejska, Ochrona inwestycji i rozstrzyganie sporów między inwestorem a państwem w umowach unijnych - zestawienie informacji, Bruksela, listopad 2013.

${ }^{58}$ S. Woolcock, op.cit. 
Tabela 4. Zasadnicze różnice $\mathrm{w}$ uregulowaniach międzynarodowych dotyczących inwestycji

\begin{tabular}{|c|c|c|c|}
\hline & BIT-y Unii Europejskiej & Model NAFTA & $\begin{array}{l}\text { Międzynarodowe umowy } \\
\text { inwestycyjne (IIAs) }\end{array}$ \\
\hline $\begin{array}{l}\text { Definicja } \\
\text { inwestycji }\end{array}$ & $\mathrm{BIZ}$ & - BIZ, portfolio oraz inne aktywa & - szeroka definicja inwestycji \\
\hline $\begin{array}{l}\text { Liberalizacja } \\
\text { inwestycji }\end{array}$ & brak & $\begin{array}{l}\text { - traktowanie narodowe } \\
\text { i klauzula największego } \\
\text { uprzywilejowania obowiązuje } \\
\text { przed i po ustanowieniu } \\
\text { inwestycji } \\
\text { - wyłączono wrażliwe sektory } \\
\text { - bezwzględny zakaz wymagań } \\
\text { eksploatacyjnych }\end{array}$ & $\begin{array}{l}\text { - szeroki zakres na podstawie } \\
\text { harmonogramów }\end{array}$ \\
\hline $\begin{array}{l}\text { Ochrona } \\
\text { inwestycji }\end{array}$ & $\begin{array}{l}\text { - klasyczne wywłaszczenie } \\
\text { - niektóre BIT-y zawierają } \\
\text { pojęcie de facto } \\
\text { wywłaszczenia } \\
\text { - bezwarunkowa zasada } \\
\text { swobodnego przepływu } \\
\text { kapitału } \\
\text { - KNU } \\
\text { - traktowanie narodowe } \\
\text { oraz równe i sprawiedliwe } \\
\text { traktowanie }\end{array}$ & $\begin{array}{l}\text { - państwo goszczące } \\
\text { rekompensuje wywłaszczenie } \\
\text { - występuje klasyczne oraz de } \\
\text { facto wywłaszczenie } \\
\text { - państwa członkowskie } \\
\text { zobowiązano do zapewnienia } \\
\text { sprawiedliwego i równego } \\
\text { traktowania inwestorów } \\
\text { zagranicznych } \\
\text { - zobowiązanie do stosowania } \\
\text { zasady traktowania } \\
\text { narodowego }\end{array}$ & $\begin{array}{l}\text { - klasyczne i de facto } \\
\text { wywłaszczenie, z ograniczeniami } \\
\text { de facto wywłaszczenia } \\
\text { - swoboda przepływu kapitału } \\
\text { podlega gwarancji w okresie } \\
\text { kryzysu } \\
\text { - KNU, z zastrzeżeniem } \\
\text { zobowiązań w ramach integracji } \\
\text { regionalnej } \\
\text { - traktowanie narodowe } \\
\text { oraz równe i sprawiedliwe } \\
\text { traktowanie, oparte } \\
\text { o międzynarodowe regulacje }\end{array}$ \\
\hline $\begin{array}{l}\text { Rozstrzyganie } \\
\text { sporów }\end{array}$ & $\begin{array}{l}\text { - inwestor-państwo } \\
\text { - trybunały arbitrażowe } \\
\text { z szeroką swobodą } \\
\text { interpretacji standardów } \\
\text { ochrony inwestycji }\end{array}$ & $\begin{array}{l}\text { - państwo-państwo } \\
\text { rozstrzyganie sporów } \\
\text { - inwestor-państwo } \\
\text { rozstrzyganie sporów }\end{array}$ & $\begin{array}{l}\text { - inwestor-państwo } \\
\text { - umowy handlowe i inwestycyjne, } \\
\text { w których określono zakres } \\
\text { arbitrażu }\end{array}$ \\
\hline
\end{tabular}

Źródło: Opracowanie własne na podstawie: S. Woolcock, European Union Policy on Foreign Investment: A Missed Opportunity?, w: Trade Liberalisation and Standardisation - New Directions in the 'Low Politics' of EU Foreign Policy, red. M. Cremona, T. Takács, Academy of European Law, European University Institute, Badia Fiesolana 2014/1.

W międzynarodowych umowach inwestycyjnych IIAs uregulowano zagadnienia dotyczące wymagań w sprawie odszkodowania oraz sprawiedliwego traktowania w przypadkach wywłaszczenia de iure. Stany Zjednoczone zawarły umowy inwestycyjne, w których określono definicję wywłaszczenia. Wszelkie zmiany regulacji prawnych służące realizacji uzasadnionych celów społecznych, ekologicznych nie uznano jako de facto wywłaszczenie.

$\mathrm{Na}$ forum instytucji międzynarodowych spory inwestycyjne za pomocą arbitrażu rozstrzyga Międzynarodowe Centrum Rozstrzygania Sporów Inwestycyjnych (ICSID), z siedzibą w Waszyngtonie, które działa pod auspicjami Banku Światowego. ICSID utworzono na mocy Konwencji waszyngtońskiej ${ }^{59}$ w 1966 r. ICSID rozstrzyga

${ }^{59}$ Konwencja o rozstrzyganiu sporów inwestycyjnych między państwami a obywatelami innych państw. 
wyłącznie spory powstałe między państwem a obywatelem innego państwa ${ }^{60}$. Obok ICSID instytucja arbitrażu istnieje również w Komisji Narodów Zjednoczonych ds. Międzynarodowego Prawa Handlowego (United Nations Commission on International Trade Law, UNCITRAL), w której stworzono Regulamin arbitrażowy.

Ochrona inwestycji w regulacjach prawa międzynarodowego związana jest z praktyką arbitrażu. Jednym z wyzwań dla międzynarodowego arbitrażu jest zakres regulacji sprawiedliwego i równego traktowania, które gwarantują rzetelny i przejrzysty proces; zakaz podejmowania arbitralnych i dyskryminacyjnych środków przez państwo przyjmujące na koszt inwestora; odstąpienie od wywierania przymusu na inwestorów; stabilny system prawny dla inwestorów w państwie przyjmującym ${ }^{61}$.

Międzynarodowy arbitraż inwestycyjny podlega krytyce ze względu na brak przejrzystości prowadzonych sporów, kryteria doboru sędziów, którzy decydują o suwerenności państwa w zakresie polityki publicznej ${ }^{62}$. Trybunały międzynarodowe rozstrzygają kwestie polityki publicznej, która powinna być domeną sądów krajowych. Arbitraż inwestor-państwo uznawany jest za stronniczy na rzecz korporacji transnarodowych, narusza zdolność państw demokratycznych do prowadzenia polityki publicznej w interesie społeczeństwa ${ }^{63}$.

Dotychczas między Stanami Zjednoczonymi a państwami członkowskimi Unii Europejskiej nie obowiązywały dwustronne umowy inwestycyjne. Strony posiadają własne regulacje prawne dotyczące ochrony inwestycji. Najważniejszą kwestią jest przeniesienie na forum TTIP formuły rozstrzygania sporów inwestycyjnych (inwestor-państwo) obowiązującej jako mechanizm ISDS. System ten obowiązuje również w umowach: CETA (którą tworzą UE i Kanada) oraz NAFTA.

Arbitraż, który upowszechnił się w BIT-ach, uznano w gospodarce światowej za najkorzystniejszą formułę rozwiązywania sporów między inwestorem a państwem przyjmującym. W okresie przed rozpowszechnieniem się BIT-ów, czyli do 1959 r., inwestorzy zagraniczni negocjowali bezpośrednio z rządem państwa przyjmującego; pozywali rząd państwa przyjmującego do sądu; inicjowali negocjacje z rządem państwa przyjmującego lub pozywali rząd państwa przyjmującego do Międzynarodowego Trybunału Sprawiedliwości, w warunkach utrzymania jego jurysdykcji.

Ochrona dyplomatyczna nie stanowiła wystarczającej ochrony dla inwestorów ze względu na polityczną nieprzewidywalność procesu. Wydatki na prowadzenie

${ }^{60}$ Guide to International Arbitration, Latham \& Watkins' International Arbitration Practice.

${ }^{61} \mathrm{Ch}$. Tietje, op.cit.

62 S. Brekoulakis, Systemic Bias and the Institution of International Arbitration: A New Approach to Arbitral Decision-Making, „Journal of International Dispute Settlement” 2013, Vol. 4, No. 3, s. 553-585.

${ }^{63}$ Ch.N. Brower, S. Blanchard, From „Dealing in Virtue” to „Profiting from Injustice”: The Case Against "Re-Statification” of Investment Dispute Settlement, 2013 Harvard International Law Journal Symposium Keynote Address, „Harvard International Law Journal”, Cambridge, January 2014, Vol. 55. 
arbitrażu mogą być znaczne (koszty postępowania sądowego przed sądami krajowymi), przegrany płaci. Postępowanie przed ISDS ograniczy ryzyko związane z ochroną dyplomatyczną lub krajowym prawem, które uważane jest za stronnicze ${ }^{64}$.

Problem „chłodzenia regulacji” można rozwiązać w TTIP, umieszczając przepisy o „prawie do regulacji” państwa przyjmującego ${ }^{65}$. W umowie o TTIP państwa europejskie muszą rozwiązać sprawę zagwarantowania rządom prawa do stanowienia polityki publicznej, mimo że zjawiska „chłodzenia regulacji” nie udowodniono empirycznie, większość roszczeń inwestycyjnych nie była związana ze stanowieniem prawa przez państwo ${ }^{66}$.

Porozumienie Stanów Zjednoczonych i Unii Europejskiej w kwestii uregulowania przepływu inwestycji w TTIP jest bardzo dużą szansą na współpracę w tym zakresie z Chinami i pozostałymi państwami na forum WTO.

\section{Podsumowanie}

Powstanie Transatlantyckiego Partnerstwa w dziedzinie handlu i inwestycji nie stanowi zagrożenia dla działania wielostronnych porozumień, ponieważ WTO należy do najważniejszych organizacji międzynarodowych. Kryzys WTO - jak powszechnie się uważa - polega na trudnościach z zakończeniem wielostronnych negocjacji handlowych Rundy z Doha. Od 1995 r. regulacje WTO stanowią skatalogowany zbiór przepisów w handlu międzynarodowym. Runda z Doha jest próbą kontynuacji procesu liberalizacji wymiany międzynarodowej, niepowodzenie tych negocjacji nie oznacza problemów z egzekwowaniem przepisów porozumień WTO.

Współpraca Stanów Zjednoczonych i Unii Europejskiej w ramach Transatlantyckiego Partnerstwa w dziedzinie handlu i inwestycji nie zastąpi wielostronnych porozumień międzynarodowych. Poza transatlantycką współpracą pozostają gospodarki wschodzące: Brazylia, Chiny, Indie, z którymi USA i UE muszą współpracować w zakresie liberalizacji handlu międzynarodowego na forum WTO. Poza TTIP pozostanie również ponad 100 krajów trzecich, w tym kraje rozwijające się, dla

${ }^{64}$ Ch. Tietje, T. Buatte, J.D., F. Baetens, Th.N. Valkanou, The Impact of Investor-State-Dispute Settlement (ISDS) in the Transatlantic Trade and Investment Partnership, Study prepared for: Minister for Foreign Trade and Development Cooperation, 24.06.2014, Ministry of Foreign Affairs, The Netherlands, Reference: MINBUZA-2014.78850, Ecorys, Rotterdam, Rotterdam 2014.

65 Prawo stron do regulacji służących osiąganiu uzasadnionych celów polityki publicznej. Por. Komisja Europejska, Ochrona inwestycji i rozstrzyganie sporów między inwestorem a państwem (ISDS) w umowach unijnych, marzec 2014, http://trade.ec.europa.eu/doclib/docs/2014/april/tradoc_152416.pdf

66 Ch. Tietje et al., op.cit. 
których istotna jest kwestia liberalizacji handlu międzynarodowegooraz rozstrzygania sporów w WTO.

Ograniczenie barier pozataryfowych i rozwiązanie innych kwestii współpracy $\mathrm{w}$ ramach TTIP umożliwi przeniesienie rozwiązań prawnych do zmian $\mathrm{w}$ wielostronnych porozumieniach handlowych WTO.

\section{Transatlantic partnership in the field of trade and investment: support or threat to multilateral international agreements?}

The article analyzes the benefits and costs of establishing the Transatlantic Partnership in the field of trade and investment for the United States, the European Union and third countries, in the context of theory of economic integration and WTO regulations. The following factors that increase the strength of the beneficial trade creation effect were analyzed: the place of the United States and the European Union in world trade, the importance of intra-regional trade in total trade, the share of sectors in the integration process, the level of customs duties before integration. The negative impact of TTIP for third countries was also examined. A The TIPP and WTO agreements were compared, particularly the attempts to regulate investor-state disputes in TTIP.

Keywords: international trade, WTO, regional trade agreements, economic integration, United States

\section{Le partenariat transatlantique de commerce et d'investissement: soutien ou menace pour les accords multilatéraux internationaux?}

L'article analyse les avantages et les coûts de l'établissement du partenariat transatlantique de commerce et d'investissement (PTCI) pour les États-Unis, l'Union européenne et les pays tiers, dans le cadre de la théorie de l'intégration économique et de la réglementation de l'OMC. Les facteurs suivants, qui augmentent la force de l'effet de création d'échanges bénéfiques, ont été analysés: la place des États-Unis et de l'Union européenne dans le commerce mondial, l'importance du commerce intra-régional dans le commerce total, la part des secteurs dans le processus de l'intégration, le niveau des droits de douane avant l'intégration. L'impact négatif de PTCI pour les pays tiers a également été examiné. Les accords du PTCI et de 
l'OMC ont été comparés, en particulier les tentatives de réglementer des différends entre investisseurs et États dans le PTCI.

Mots-clés: le commerce international, l'OMC, les accords commerciaux régionaux, l’intégration économique, les États-Unis

\section{Трансатлантическое партнерство в области торговли и инвестиций (TTIP) - поддержка или угроза для многосторонних международных соглашений?}

В статье анализируются преимущества и затраты создания трансатлантического партнерства в области торговли и инвестиций для Соединенных Штатов, Европейского союза и третьих стран в контексте теории экономической интеграции и правил ВТО. Проанализированы были факторы, которые, благодаря эффекту создания торговых потоков, способствуют повышению уровня благосостояния: место Соединенных Штатов и Европейского союза в мировой торговле, важность внутрирегиональной торговли в общем объеме торговли, доля различных секторов в процессе интеграции, уровень таможенных пошлин до интеграции. Исследовано негативное воздействие TTIP на третьи страны. Автор также сравнил важнейшие области, по которым велись переговоры по ТTIP, и соответствующие им положения в соглашениях ВТО, в частности попытки регулирования споров инвестор-государство в ТTIP.

Ключевые слова: международная торговля, ВТО, региональные торговые соглашения, экономическая интеграция, США 